JRIT

14,2

Received 13 June 2019 Revised 17 October 2019 12 December 2019 Accepted 18 January 2020

\section{Public libraries' role in supporting e-learning and spreading lifelong education: a case study}

\author{
El-Shaimaa Talaat Abumandour \\ Information Institutions and Professional skills Department, Bibliotheca Alexandrina, \\ Alexandria, Egypt
}

\begin{abstract}
Purpose - Public libraries play a pivotal role in supporting education and literacy. They provide numerous services, activities, collections and resources for education and leisure. Bibliotheca Alexandrina (BA) is an international renowned public library that provides numerous services for different users worldwide. E-learning is an emergent and promising method for teaching and learning different subjects such as the science, technology, engineering and mathematics (STEM). The e-learning educational system is quite novel in Africa and the Middle East; hence, this paper presents the whole concept to the reader. In addition, it demonstrates number of e-courses tackling different domains provided by different educational institutions, national and public libraries worldwide.

Design/methodology/approach - In 2017, the BA inaugurated its e-learning services to cope with the new educational trend and to consolidate the lifelong learning concept in the community. The author showed special interest to the case of e-learning in the BA, as it is a regional public library. The main idea of this paper is to attract attention toward public libraries as a promising venue for e-learning implementation for general knowledge, library information sciences, soft skills, elementary and informal STEM education. The paper discusses in details e-learning and its characteristics.

Findings - In addition, the paper compares traditional education (face-to-face) with e-learning education, mentions both their pros and cons and recommends blending the two educational methods as they complement each other. Furthermore, the author has selected a sample of different STEM e-courses (203 different e-courses). These e-courses were selected to assert the possibility of presenting STEM topics in the form of e-courses.

Originality/value - This study would be one of the emergent research studies that connect e-learning to both STEM disciplines and public libraries. Additionally, this research highlights the importance of public libraries and all the services they provide. In the mean time, it shed light on the important and unique role of specialized librarians. Briefly, public libraries with all their resources, services and expert librarians could provide an exceptional e-learning experience to their community and be of great help to educational institutions and organizations.
\end{abstract}

Keywords E-learning, Public libraries, STEM, Traditional education

Paper type Case study

\section{Introduction}

During the late eighteenth and early nineteenth centuries, the whole world witnessed the industrial revolution, which had a powerful impact on all aspects of human lives. Since then, people have been facing unstoppable challenges in education, social, economic and environmental welfare. The most outstanding breakthrough was achieved in both the science and technology fields. Science and technology are key elements toward development in different domains, such as economics, trade, industry, health improvement, education and infrastructure. Therefore, innovative and advanced education systems have lately attracted

(C) El-Shaimaa Talaat Abumandour. Published in Journal of Research in Innovative Teaching \& Learning. Published by Emerald Publishing Limited. This article is published under the Creative Commons Attribution (CCBY 4.0) licence. Anyone may reproduce, distribute, translate and create derivative works of this article (for both commercial and non-commercial purposes), subject to full attribution to the original publication and authors. The full terms of this licence may be seen at http://creativecommons. org/licences/by/4.0/legalcode
Journal of Research in Innovative Teaching \& Learning Vol. 14 No. 2, 2021 pp. 178-217 Emerald Publishing Limited 2397-7604 DOI 10.1108/JRIT-06-2019-0063 
more attention (Chetty, 2012) and (Eagleton and Manolopoulou, 2017). Recently, the information and communication technology (ICT) field has been extensively developed. The growing demand for novel educational techniques and the emerged ICT produced a new method of learning called e-learning. E-learning is an abbreviation that refers to electronic learning; it fluctuates between supporting classroom education to providing totally online distance-education. E-learning emerged due to the increasing number of population and learners, as well as an increasing demand for better, convenient and feasible education systems. Coinciding with this, the first computer-based learning system, PLATO, was developed by Bitzer in 1962 at University of Illinois. Additionally, there were pioneer researchers in this field such as Porter (1959), Uttal (1962) and Suppes (1964) (Bhatnagar, 2016).

\section{State-of-the-art}

Different authors have defined e-learning in the published literature according to the topic covered, providers, techniques and tools used. Sharifabadi (2006) defined e-learning as the use of the Internet to disseminate educational resources and learning materials. Furthermore, the system develops interaction between learners and instructors and/or trainers to enhance the teaching and learning experience (Bhatnagar, 2016). In 2009, Kumbhar defined e-learning as a learning system supported by electronic media. The e-learning educational system depends on computer devices, networks, telecommunication, storage and sharing technology. Moreover, the National Science Teachers Association (NSTA, 2016) defined e-learning as an efficient teaching technique developed by gathering digital content and learning support and services. NSTA stated that e-learning could be used to enhance the teaching of science and technology.

The author intended to point out the role of public libraries in spreading and supporting the e-learning system. Recently, this topic was discussed from different perspective in the published literature (Abbasi and Zardary, 2012; Han and Yates, 2016; Kumbhar, 2009). Abbasi and Zardary were interested about the role of digital libraries on supporting e-learning. They stated that digital libraries could provide both digitized services and electronic resources via Internet to support e-learning. Han and Yates presented a case of an academic library called Monash University Library, Australia that has adopted e-learning system for both research and learning skills development within the university. In this study, the authors showed special interest about the library staff members gained competencies and the impact of this on the sustainability and improving of the e-learning strategy. They concluded that their case study could give a positive sign for organizations which consider integrating e-learning. Additionally, they recommended the presence of qualified and centralized e-learning team who could create and develop easy to use manuals and support e-learning techniques. In 2009, Kumbhar presented a review of e-learning initiative in Library Information Science (LIS). The author stated that traditional and e-learning education systems are complementing each other in spreading LIS education.

\section{Different educational systems (e-learning vs traditional learning)}

The e-learning system is a web-enabled system that provides information and knowledge to various audiences anywhere, anytime. There are different terminologies for e-learning, such as online education, web-based training/learning (WBT, WBL), virtual university, computer-based education, etc. E-learning systems could support educational and teaching systems by using modern ICT tools and through effective use of different educational resources. Furthermore, e-learning facilitates lifelong learning and self-pace education. Time and place cannot limit the e-learning education, and e-learners could enroll and learn any topic anywhere, 24/7.

Nowadays, a large number of organizations are implementing e-learning educational systems as a flexible and timesaving method to train and increase the competence of their
Role of public libraries in e-learning 
JRIT

14,2

employees. In the meantime, educational institutions such as universities and research centers are heading toward the adoption of e-learning. Educational institutions usually combine face-to-face (traditional/classroom) learning and e-learning systems in what is called "blended learning" (NSTA, 2016). Currently, e-learning uses diverse tools and techniques to facilitate the covering of numerous topics and fields; starting from LIS to engineering sciences, which will be discussed in detail later. Pros and cons of both e-learning and traditional (classroom) learning systems can be briefly outlined in Table I.

From all the above propositions, it could be noticed that both learning systems have advantages and disadvantages. The author recommends using both learning systems, which is called the blended system, which is a combination of both e-learning and traditional methods.

\section{Library definition}

Throughout time, libraries have supported education and played a key role in literacy dissemination. The word "library" is derived from the Latin word liber, which means "book". Libraries ensure the provision of educational materials, books collections, electronic resources, periodicals, multimedia materials, referral services, etc. At the same time, this term could refer to the building or space itself, which includes all the previously mentioned materials (Shukla et al., 2013).

In 1994, International Federation of Library Associations/The United Nations Educational, Scientific and Cultural Organization (IFLA/UNESCO) (1996) defined public libraries as the perpetual source of information and knowledge. Public libraries promote lifelong learning, cultural development, peace and social welfare for the public. Public libraries are hubs of information, providing all kinds of knowledge available to users nationally and internationally. Public libraries help communities to develop, improve and carry out decision-making independently. The manifesto stated that public libraries deliver different services and materials for various categories of users based on equity and equality. In addition, IFLA/UNESCO recommended public libraries to disseminate special services, materials and reference sources among users who cannot have access to the regular libraries services and materials, such as linguistic minorities, disabled, hospitalized or imprisoned people (IFLA/UNESCO, 1996).

Users of different categories could easily access all the provided materials and organized collections through the help of well-trained and skilled librarians. Skilled subject librarians act in significant roles in both public and academic libraries. Generally, these tasks include collection-cataloging, development, reference services, building collaboration with educational organizations (schools, universities and research institutions) and providing instructional lectures to users.

The main aim of this study is to investigate the potential role of public libraries in spreading science, technology, engineering and mathematics (STEM) e-learning education. In this paper, the author will focus on STEM e-courses available, list providers (libraries, educational organizations, educational platforms, etc.) and the learning management system (LMS) used to present scientific context. Educational resources could take different formats (text, videos, interactive presentations, audio, animation, etc.) according to the subject covered. Finally, the main target of this study and previously published studies is to shed light on the role of libraries in supporting e-learning education, developing both e-learning and traditional educational systems and to use the advantages of both systems to the maximum for the sake of learners.

\section{Types of libraries}

Libraries have essential influence on education. Libraries could deeply support education by different means. Different types of libraries are listed and defined below: 


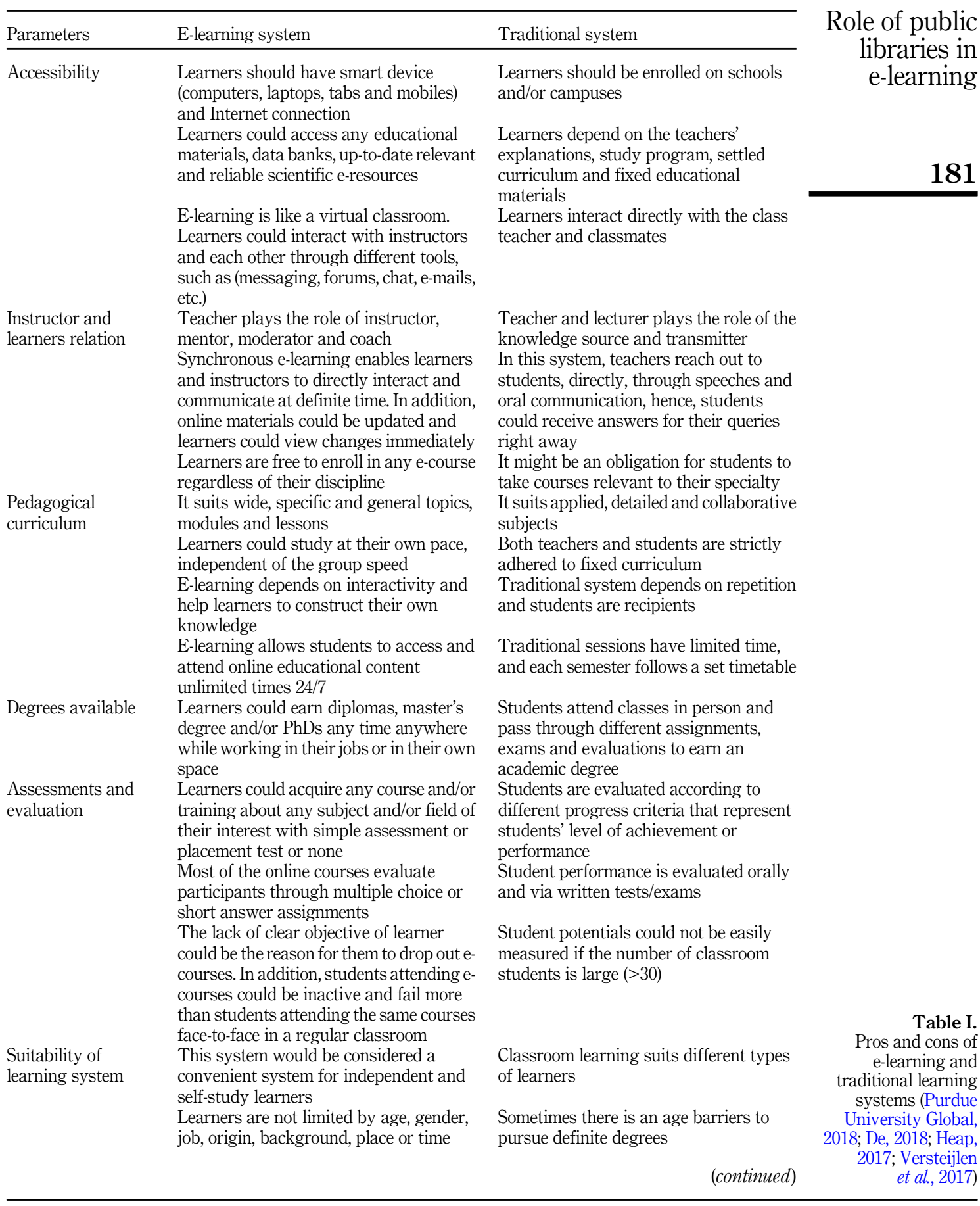




\section{JRIT 14,2}

\section{2}

\begin{tabular}{lll}
\hline Parameters & E-learning system & Traditional system \\
\hline
\end{tabular}

It could be hard to illustrate courses, which require certain tools and kits

Learners skills $\quad$ E-learning system could enhance selfmotivation, creative thinking and time management skills

Learner is completely his/her own boss; learner is responsible for completing all the online courses requirements such as viewing lectures, interact with peers and instructor, submitting and required assignments before the deadline (selfdirection)

Learning system E-learning is a fast way of presenting time-consuming lessons. Learners could retrieve and save the online sessions and electronic resources to revise them anytime anywhere

Expenses

Learners could save travel expenses, course materials and accommodation fees by applying for e-learning courses

Environmental impact

E-learning education has less impact on the environment. It is a paperless educational system; hence, it saves about 90 percent power and generates 85 percent less amount of $\mathrm{CO}_{2}$

Technical barriers Communication and technology barriers could limit the e-learning process. In addition, computer illiteracy endangers the spreading of the e-learning method Transforming teaching material into interactive e-course is time-consuming and requires good knowledge of tools and technology available. Although by the end of the e-learning experience learner would enhance his/her digital skills
It could be preferable for subjects, fields and programs that require hands-onapproach

Traditional system is efficient, and it could enhance self-motivation and discipline

This system could build strong relations between students and teachers.

Meanwhile, it helps young students improve their personalities, increases their self-esteem and assists them in avoiding exam panic

The time required for the teaching process is $20-60$ percent higher than the e-learning method

Traditional learning cost is higher than elearning (investments, educational buildings, academic staff, teachers and employees' salaries, etc.)

Carbon footprint increases due to students and academic staff traveling and transportation

If teacher or lecturer does not integrate technology within curriculum content, this would decrease the digital and technological skills of students

Table I.

\section{Public library}

As mentioned earlier, public libraries are national organizations, funded and supported by governments and communities. Public libraries have a great impact on society, and they play the vital mission of spreading literacy and lifelong learning to improve and fulfill needs of society. Public libraries are no longer limited to their buildings, physical collection or indoor services. Most public libraries successfully cope with the publics' increasing demands, as well as technological and educational challenges. Thanks to open access and open educational resources, public libraries can offer educational materials, courses, trainings, scientific publications, etc. to users. They manage to deliver their services not only face-to-face but also online. Earlier, all these resources were restricted to educational institutions, accessed in definite places, during specific times and at fixed prices. Nowadays, users and students have a vast amount of raised references on different topics, such as educational and reference resources, digital tools and services. Users access public libraries (physically or virtually) seeking the guidance and help of skilled and competent librarians. 
Thus, public libraries should be classified as information hubs and central sources of a multitude of educational materials, ranging from traditional to online-based courses. Nevertheless, public libraries should collaborate with regional educational institutions (schools, universities and adult learning) to execute students' demands and to avoid redundancy (Lifelong Learning, 2012; Balapanidou, 2015). Creelman (Lifelong Learning, 2012) stated that public libraries depend on their librarians' professionalism and expertise. Balapanidou (2015) reviewed a number of published studies and stated that public libraries have played a fundamental role in every community by providing various services to different user categories, for both educational and recreational purposes. Nowadays, they are facing challenges in keeping up with technological evolution, moreover, maintaining and upgrading their services. In the meantime, they should reach and support all types of users, such as the literate, illiterate, children, youth, adults, the disabled, minorities, the hospitalized and/or imprisoned people. There are numerous examples of illuminating and inspiring public libraries, such as the Library of Congress (Washington D.C., USA), Bibliothèque Nationale de France BNF (the National Library of France) and the Bibliotheca Alexandrina (BA) (The Library of Alexandria). In this study, the author will focus on the BA and its different facets. This paper will highlight the efforts done by the Library of Alexandria to spread and increase public participation and support the e-learning educational system.

\section{Special library}

Special libraries could be briefly defined as establishments concerned with a specific subject or field with their own specialized collections. They provide help and guidance for their particular clientele (academia or professionals) (Bilawar, 2013). Generally, specialized libraries are involved in any research and/or educational process in any academic, industrial and business organizations. Special libraries include the following:

(1) Science libraries;

(2) Law libraries;

(3) Medical libraries;

(4) Music libraries and

(5) Museum libraries.

\section{Academic library}

Academic libraries are entities that fall under the umbrella of educational or academic organizations, such as schools, universities, colleges or research institutions. They have two fundamental and integral functions: first, to support the curriculum of the educational organization, and second, to promote research in these organizations. Academic libraries are usually located within campuses, and they have materials and collections that help teachers, professors, researchers and students to fulfill their missions.

Examples of academic libraries are as follows:

(1) American University in Cairo Libraries and

(2) University of Lorraine Libraries

\section{Digital library}

Digital libraries are emerging paradigms of the rapid development of ICT. Trivedi (2010) defined digital libraries as virtual entities offering very large organized collections stored in
Role of public libraries in e-learning 
digital formats that can be accessed remotely. They consist of three main elements: the library materials (data), information about the library materials (metadata) and the performed functions that link all the library elements (processes) (Rajput, 2013).

Examples of digital libraries are as follows:

(1) Egyptian Knowledge Bank (EKB);

(2) Peking University Digital Library (China) and

(3) Digitale Bibliothek Information und Medien (Germany).

Recently, it is noticeable that a large number of traditional libraries are heading towards digitizing their collections.

\section{Bibliotheca Alexandrina (BA)}

The BA was officially reborn on October 16,2002 . The main target of the modern library is to be a hub of merit in acquaintance creation and spreading. In addition, the BA aspires to be a destination of interchange, learning, tolerance and understanding. This paper will discuss the BA e-learning services as the case study.

The BA provides numerous services for all users. Most of these services are listed on the BA website. The core services, which are offered by the BA, are listed hereunder:

(1) Free computers, Internet access and free Wi-Fi;

(2) Electronic resources (open and closed access);

(3) Community events;

(4) Study rooms and reading space;

(5) Printing and copying centers;

(6) Reference and inquiry services;

(7) Adult learning courses;

(8) The BA catalog (enables users to search for items anytime, anywhere);

(9) Specialized courses for librarians;

(10) Researchers' services;

(11) Celebrity authors events;

(12) Numerous cultural and scientific events and

(13) Exhibitions, seminars, conferences, concerts and theatrical performances.

\section{BA e-learning services}

The BA has established an online educational service in January 2017. The main aim of this service is to enable the BA users (from all over Egypt, the Arab world, Africa and the worldwide) to attend the BA educational courses. This service will introduce the selflearning concept to the BA users and will increase their enthusiasm for selfimprovement. This service ensures providing sustainable educational services for all types of users anytime anywhere. The BA e-learning services aim to provide access to massive open online courses (MOOCs), online courses and other e-learning modules. In addition, the BA e-learning Services strive to provide e-learning courses about different 
topics not limited to LIS. The BA improves its e-learning resources, techniques and materials indoors and keen to cooperate with other educational organizations and institutions. This could be a positive indication for other public libraries looking forward to implement e-learning system. The BA develops its e-learning service internally depending on the subject expert librarians and externally by cooperating with educational institutions such as Alexandria University, Senghor University, The National Superior School of Information Science and Libraries (ENSSIB), the National Library of France (BnF), etc. Table II shows the available e-courses and online orientation sessions provided by the BA e-learning services.

All the previously mentioned e-courses, sessions and trainings are presented using the Moodle platform. The BA e-learning services adopted Moodle platform due to its special features such as:

(1) Open access learning management system (LMS);

(2) Free platform with unlimited time;

(3) User-friendly platform (learners, tutors and administrators);

(4) A well-organized and easy to navigate platform;

(5) The design to be responsive and accessible (it is easy to navigate on both desktops and smart devices);

(6) Multilingual capability platform (The BA uses Arabic, English and French);

(7) Various modules, features, tools, and customizable themes and layout;

(8) Modular design that simplifies syllabus and curriculum arrangement;

(9) Interactivity between tutors and learners through various activities and collaborative tools (i.e. forums, chats, wikis, glossaries, databases, quizzes, etc.);

(10) Easy plugin (sign in) management;

(11) Consistent security updates;

(12) Supports multimedia integration (courses could be uploaded in all types of formats as text and multimedia files);

(13) Can integrate with different cloud storage services to share files such as MS OneDrive, Dropbox and Google Drive and

(14) Implements both synchronous and asynchronous learning.

\section{Application of e-learning in international public libraries}

A number of published researches have indicated that public libraries are playing a key role in spreading and serving as remote sites for e-learning. Public libraries play a critical role in developing and expanding e-learning education (Proudfoot and Kebritchi, 2017). The traditional role of a public library is to offer information resources for users and play as information keepers. Nowadays, this role should be expanded to include being information providers and a gateway to knowledge (Sharifabadi, 2006). In this study, the author has listed a number of e-courses provided by three examples: the National Library of New Zealand, the American Library Association (ALA) and Australian Library and Information Association in Table III. The three selected examples are using Moodle as the LMS. From the previous context, it is clear that e-learning education is growing and developing rapidly; hence, libraries are pressured to support and embrace e-learning at massive scale.
Role of public libraries in e-learning 


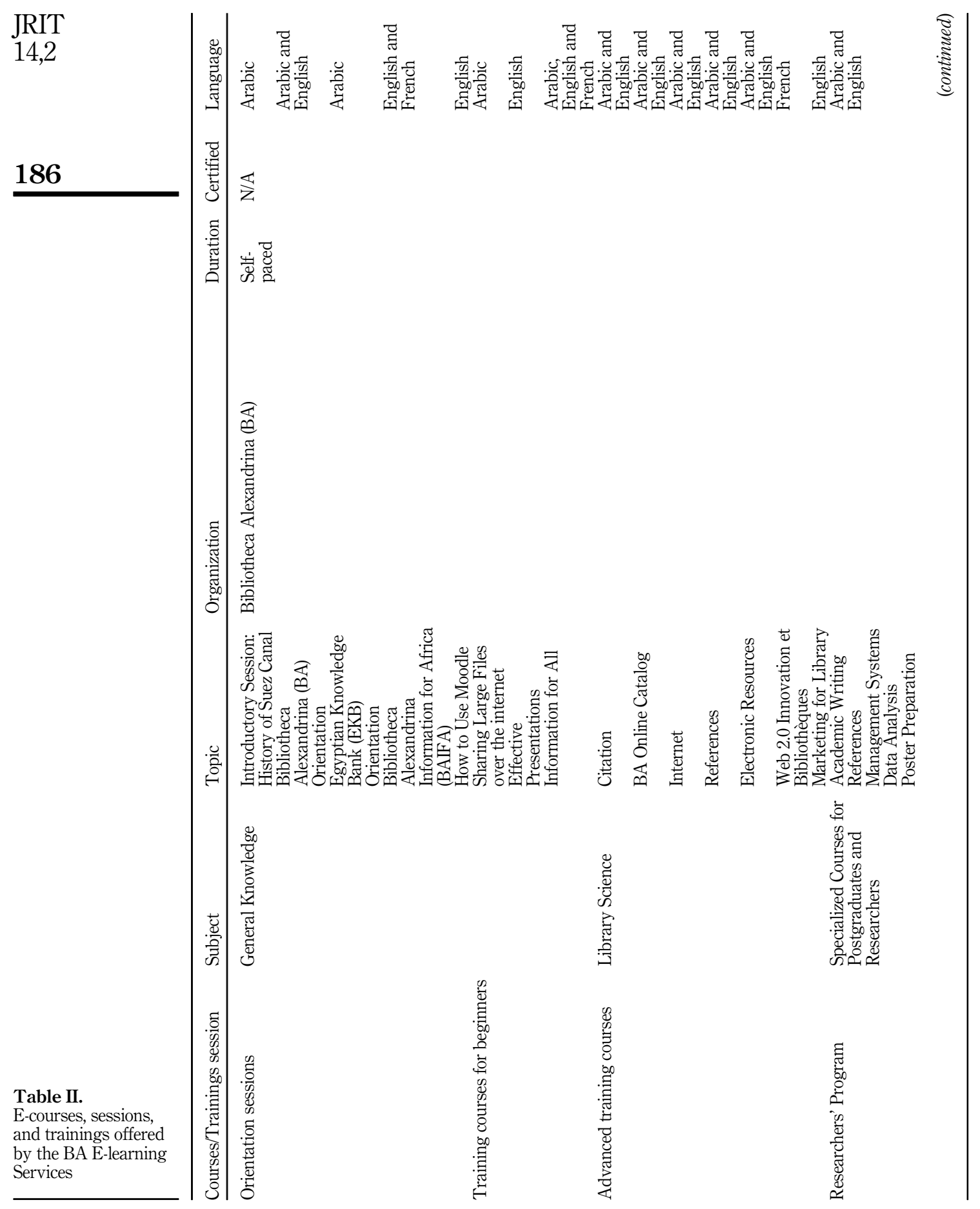




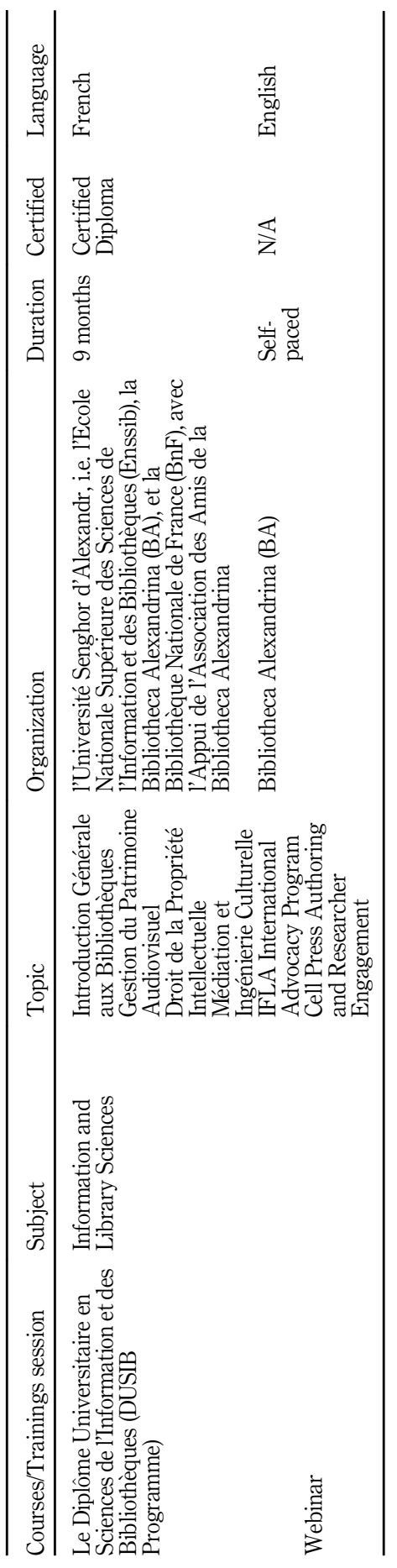

Role of public libraries in e-learning

Table II. 


\section{JRIT 14,2}

188

Topic
Inquiry Learning: The Role of
Resources to Inspire and Inform
Building a Responsive Collection
for Your School Library

Developing Digital Literacy in

Your School

Raising Readers: School and

Home Connections

Sail into Summer Reading:

Keeping Students Reading Over

Summer

Developing Your School Library

Services

Organization and Personnel

Management

Science, Technology,

Engineering, and Math (STEM)

Programs Made Easy

Fundamentals of Cataloging

Fundamentals of Metadata

Mindfulness in Libraries

Budget and Finance

Making Games and Online

Interactive Content

Fundamentals of Acquisitions

Fundamentals of Electronic

Resources Acquisitions

Fundamentals of Collection

Development and Management

Fundamentals of Collection

Assessment

Fundamentals of Preservation

Whole Person Librarianship:

Social Work Concepts for

Holistic Patron Services

Project Management in Libraries

E-Resources Licensing: Best

Practices

Building An Accessible and

Inclusive Library Community

Contemporary Issues in Action:

Ethics for Librarians

Storytelling with Puppets

Fundraising and Grantmanship

Who Manages, Who Leads?

Negotiating License Agreements

and Pricing with Confidence

Planning and Management of

Library Buildings

Marketing the 21st Century

Library

Table III.

Management of Technology

E-courses, sessions and STEM in Libraries

trainings offered by

international libraries

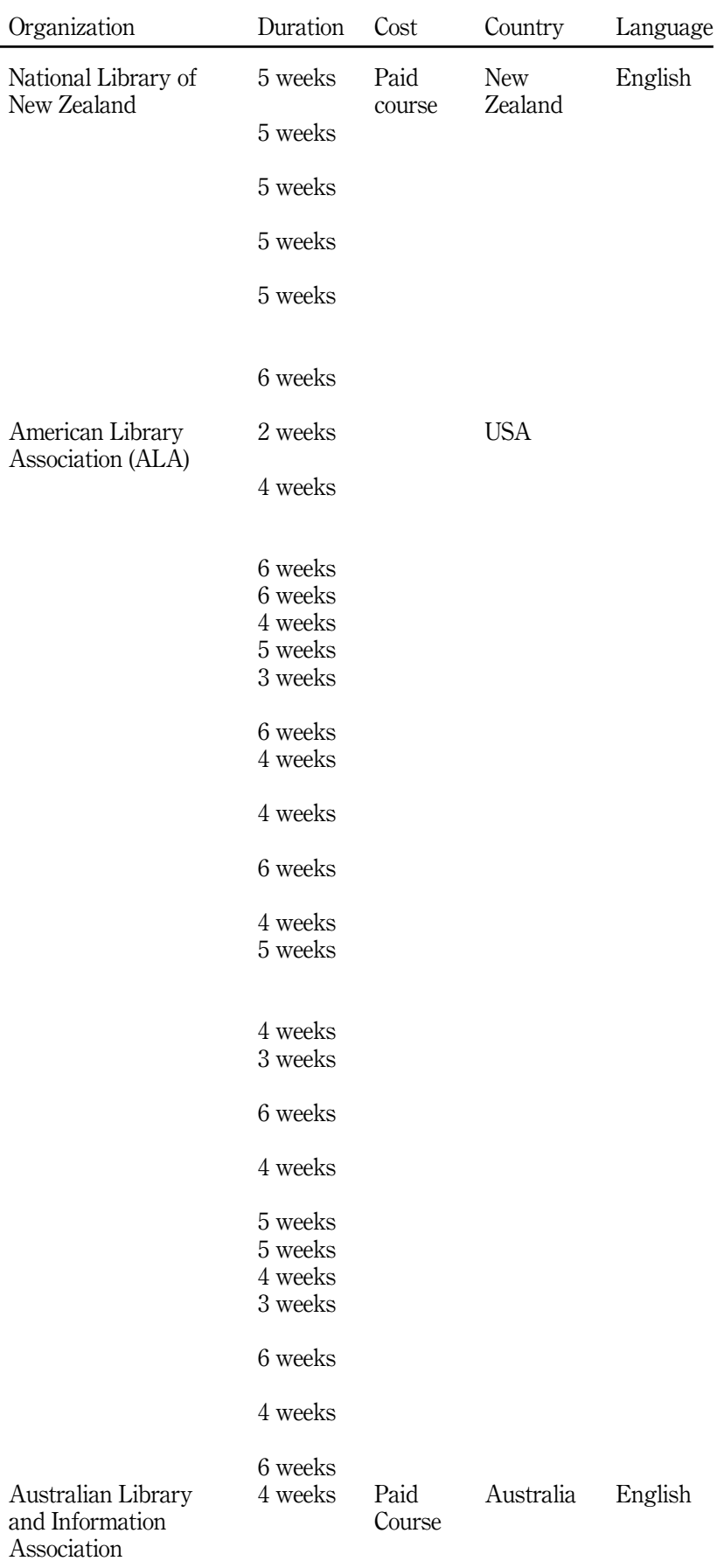




\section{Research design and sampling procedure}

This study implemented an empirical data analysis, which applied qualitative and quantitative approaches to data collection and analysis. The collected data were retrieved via web searches. The collected data were e-courses provided by different universities and educational organizations and hosted by different MOOCs platforms. In order to make the study representative, data were collected based on three criteria: the selected e-courses should be limited to STEM topics, should have best review and rating, the educational institution/ organization which provided the e-course should have high-ranking. The selected data are listed in Table AI.

\section{STEM e-learning education}

In this part, the author has selected a sample of different STEM e-courses that are relevant to the spectrum of the study. Additionally, the author was keen to choose e-courses based on the following factors to narrow down the sampling process:

(1) Topic is limited to STEM fields;

(2) E-courses should have best review and rating and

(3) Educational organization/institution which provided the e-courses should have high ranking.

The list of these e-courses are shown in. Table AI. Figures 1 and 2 illustrate the STEM fields were covered, the number and percent of the e-courses provided.

From the collected data, the selected STEM e-courses were categorized into five main classes: the scientific discipline or field, the educational organization, the country, language of the e-course and the used platform. From Figure 3, it is noticeable that the chosen STEM e-courses are offered by countries in the following order: the USA, the UK and Egypt. Switzerland, Australia, South Africa, Canada, Denmark and Italy offered the remaining 8 percent of the covered STEM e-courses. Accordingly, the topics covered by the USA and UK are illustrated in Figures 4 and 5. The collected data show that the fields are represented as follows: 22.3 percent computer science, 12.9 percent engineering, 12.4 ;percent medicine, 11.4 percent biology, 10.9 percent physics, 5.4 percent mathematics, 5.4 percent STEM, 5 percent chemistry, 5 percent environmental sciences, 3 percent statistics and probability, 2.5 percent astronomy, 1.5 percent science, 1 percent bioinformatics, 0.5 percent Earth science, 0.5 percent quantum mechanics and 0.5 percent urban planning.

\section{Discussion}

Recently e-learning has shown significant expansion and attracted learners' attention worldwide. E-learning assists learners who are geographically remote from educational institutions, unable to participate as full-or part-time campus students and grownups. Elearning promotes the "lifelong-learning" concept, ensures learning equity and increases the competence of workforce in order to cope with the overwhelming development in the modern economy and industry. Generally, e-learning depends on three main factors:

(1) The instructor (teacher or tutor) and learner;

(2) Educational institution, which creates and influences the process and

(3) LMS that provides two-way communication between instructor, educational institution and learners.
Role of public libraries in e-learning 
JRIT

14,2

190

Figure 1.

STEM E-courses provided by different educational organizations

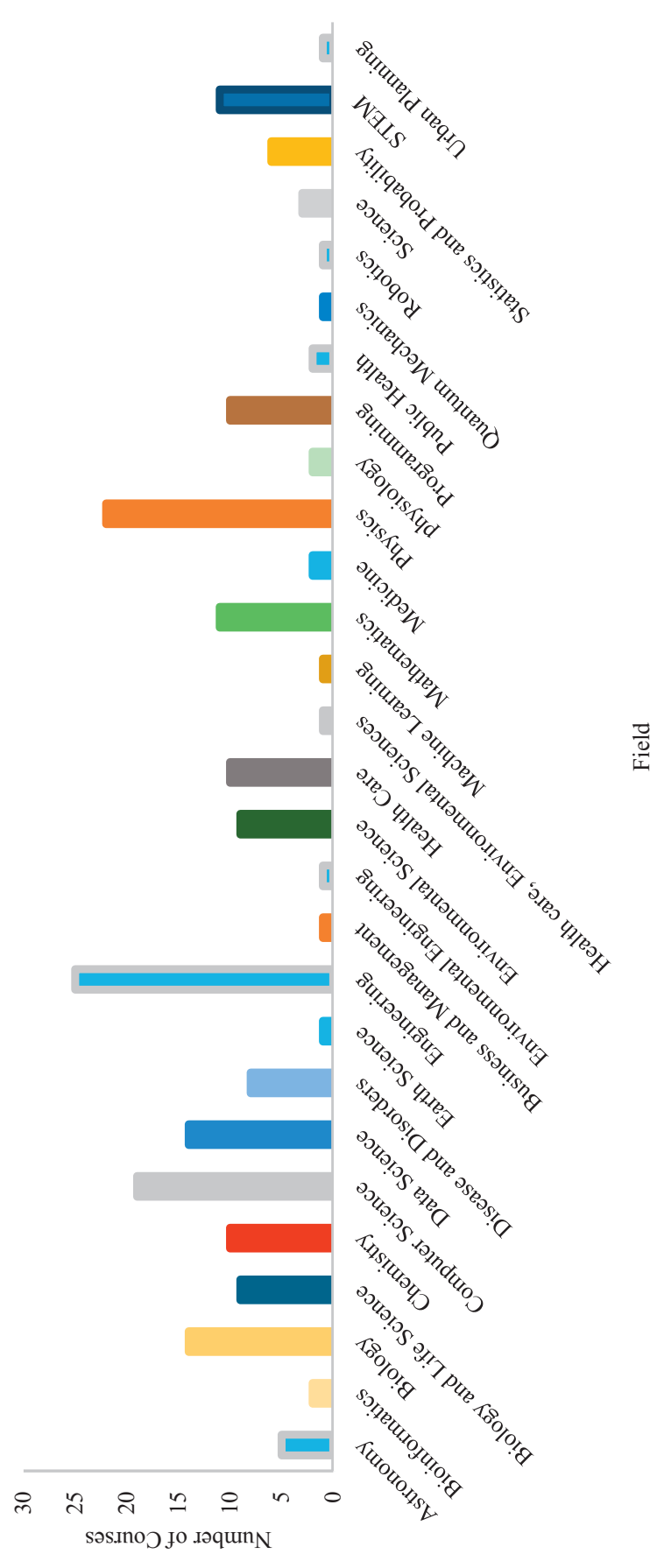




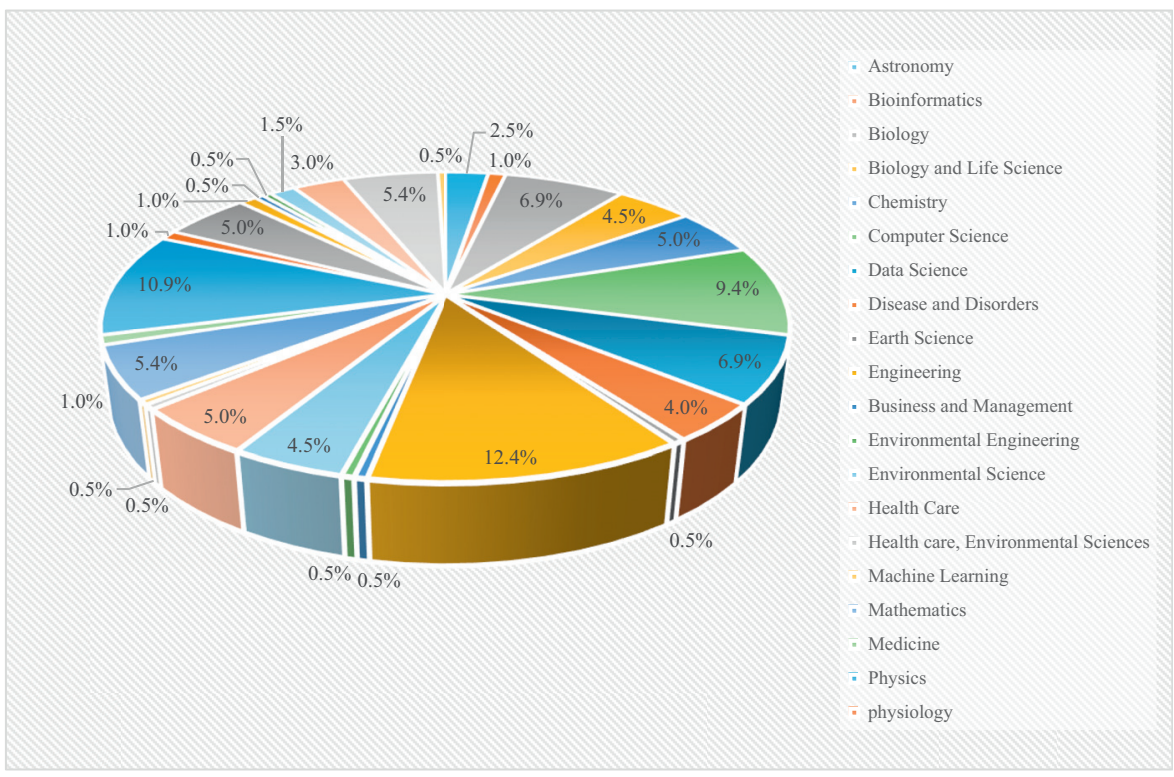

\section{Role of public libraries in e-learning}

191

Figure 2. The percent of the covered STEM ecourses

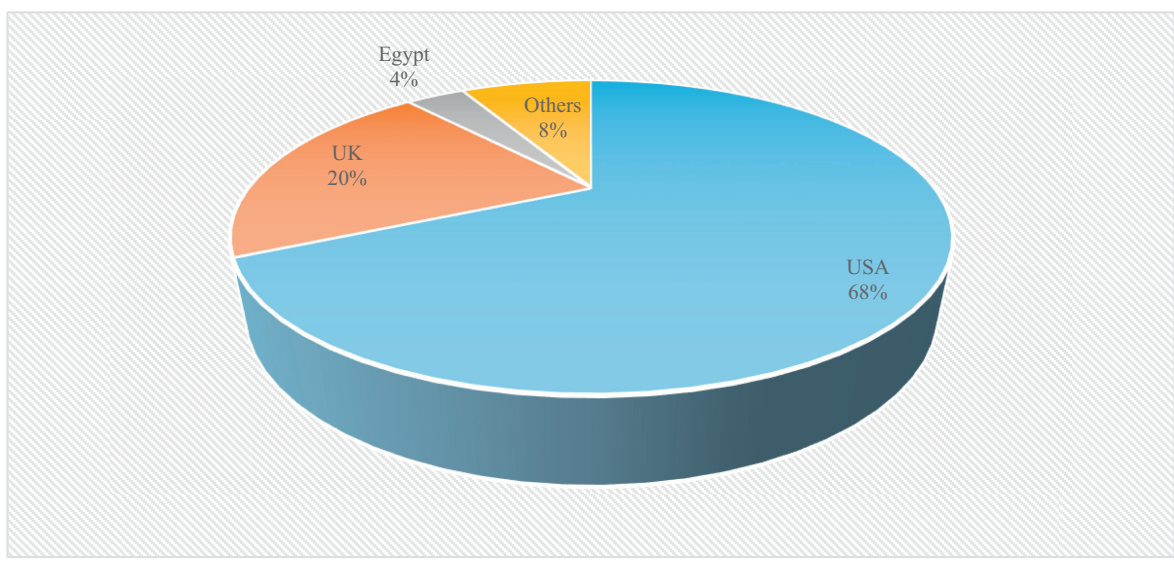

Figure 3. The percent of the covered STEM e-

courses

In addition, LMS carries the e-courses materials and offers different tools and techniques to evaluate and transform courses into interactive and interesting e-courses.

In the twenty-first century, it is clear that science, technology, engineering and mathematic fields have great influence on the labor market (Chen et al., 2018). These fields are in continuous and hectic expansion. As a result, educators and learners are in great need of implementing technological innovations to become more engaged with STEM education and its latest topics. Nowadays, a number of researchers, scientists and professors are searching for more innovative techniques for STEM teaching. A number of published studies in literature have shown that e-learning plays a key role in STEM education (Tiwari, 2011). STEM education via e-learning could be of great help to schools and university students. E-learning could foster science literacy and introduce new scientific findings to the public. 


\section{JRIT \\ 14,2}

192

Figure 4 .

The STEM topics covered by the USA

Figure 5.

The STEM topics covered by UK
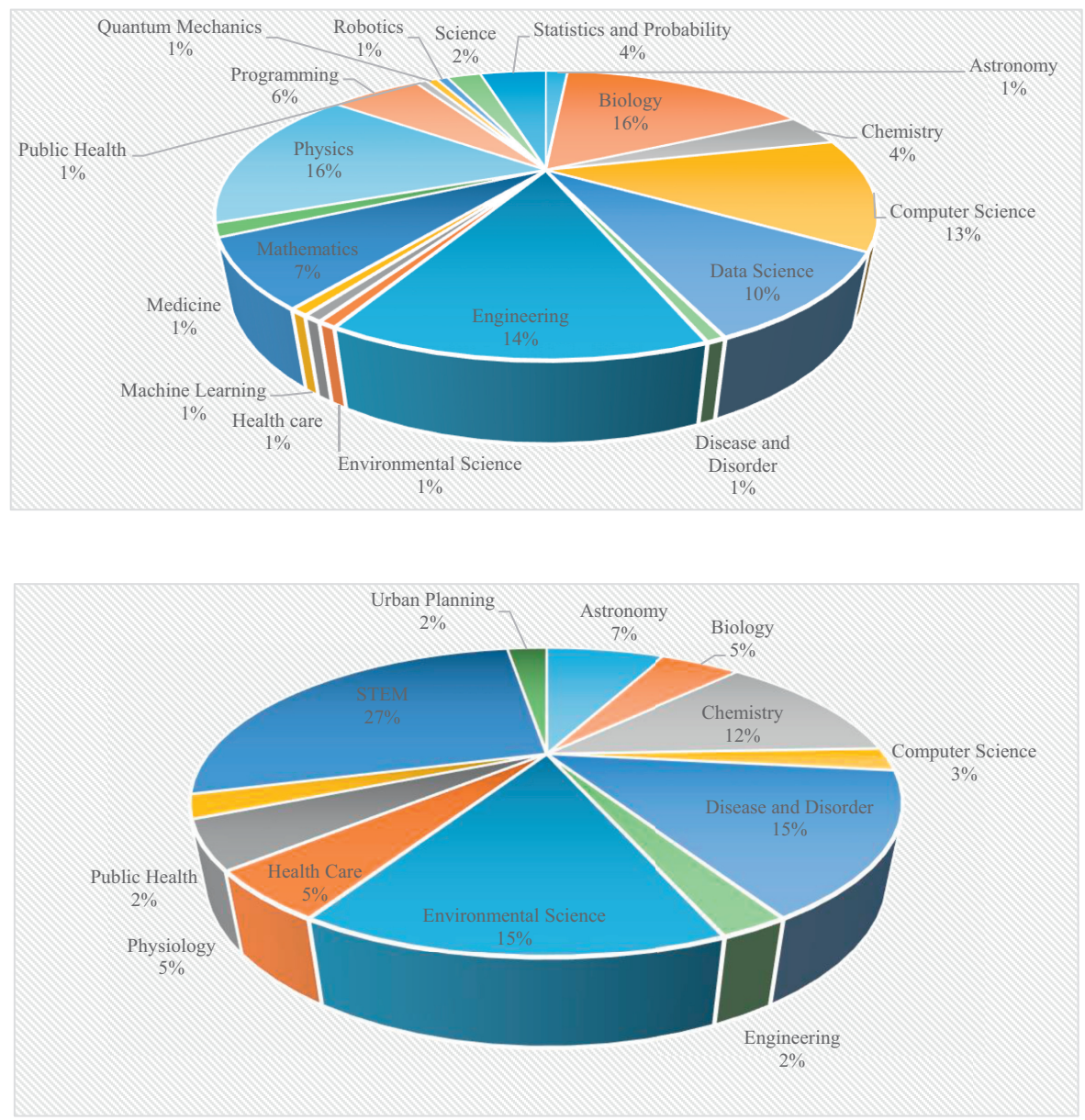

From the collected data, it is obvious that STEM education via e-learning is widely spreading, covering mostly all topics and offered by distinguished institutions worldwide.

From all the above propositions, international educational, commercial and cultural institutions have created numerous programs and e-courses. A number of international agencies are supporting e-learning, such as the Commonwealth and the World Bank Group. Public libraries have supporting elements and great potential to empower them to play significant roles in developing and spreading e-learning education. Each public library has different scope and objectives, nevertheless, all presented cases showed positive indications that e-learning education could be offered by public libraries depending on their resources, skilled librarian staff and collaboration with different educational organizations (Universities, research institutions, information services' centers, etc.). However, most of the libraries providing e-learning services are confined to the LIS field. The collected data show that STEM subjects are successfully presented in interactive e-courses carried by LMS. The author suggests that as learners participate in engaging positive STEM elearning courses, they would become more concerned with STEM and STEM-related careers. From the collected data, it is obvious that public libraries have full capacity 
(potential) to offer e-learning in STEM fields. This paper points out the value in having elearning team experts, this team could provide simple and/or deep scientific content; provide, support and develop e-learning technologies; as well as create interactive and entertaining e-courses. IT support teams could provide consultation to the e-learning teams. In this study, the author has attempted to shed light on the role of the BA in e-learning as a case study. The BA is a public library emerged as a hub for excellence providing a wide range of innovative services. Among the remarkable services come the BA e-learning services. The nascent service aims to deploy the lifelong learning approach and introduces emerging scientific findings in interactive and simple means to specialized and nonspecialized audience. The BA e-learning services will achieve these goals by developing collaboration between the BA and different educational institutions (schools, universities and research institutions).

The BA e-learning service during three years was able to offer different e-courses categories that could match the requirements of various users (general and lifelong learner, LIS specialist, researchers and postgraduates). The BA in cooperation with Senghor University, The National Superior School of Information Science and Libraries (ENSSIB), the National Library of France (BnF) was able to award the DUSIB 2018-2019 alumni their diploma and launched its second round 2019-2020. In year 2019, it offered the Researchers' Program, which covers different topics, targets researchers and postgraduates and aims to enhance their competencies. Researchers, scientists and professors from academia and specialized librarians could cooperate to prepare and provide interactive, hands-on and useful scientific e-courses. The author would like to highlight the idea that the role of public libraries is providing online education to assist educational organizations, enhance society literacy, increase public awareness and to embrace lifelong learning concept. Indeed, public libraries could be partner to educational organizations not a substitute or alternative. There are varieties of e-learning platforms that produce STEM e-courses for individuals. Many library users are looking to public libraries to provide access to these platforms. Gale course, Knowledgecity and Skillsoft are examples of platforms that provide various e-courses topics for libraries. Briefly, public libraries with all their resources, services and expert librarians could provide an exceptional e-learning experience to their community and be of great help to educational institutions and organizations.

\section{Conclusion}

There is a diversity of e-courses, activities and programs that promote STEM education, but there are limited models of extending STEM e-courses by employing e-learning platforms in public libraries. These trials could be a positive sign that public libraries are promising key players in developing and supporting e-learning education in different fields not only in LIS. There is an increased need to augment STEM education via e-learning in a technology-driven society and generate initiatives that develop STEM literacy and increase individuals' awareness toward STEM, health, environmental issues and related professions. E-learning is considered one of the most rapid and emergent industries. It is obvious that e-learning has left a significant footprint on educational systems worldwide. Nowadays, public libraries with their immense capacities open a new gateway toward e-learning. Public libraries have an important and critical role to disseminate knowledge, education and literacy to the community. They should ensure the quality of the provided educational material and services. Public libraries should work on delivering their services equally to all types of public users. To achieve their goal in the e-learning industry, public libraries should build strong collaborations and partnerships with different educational institutions. Specialized librarians are uniquely qualified to become active members of the e-learning team and assist both their libraries and the educational institutions to effectively integrate STEM subjects into
Role of public libraries in e-learning 
e-courses. Public libraries should focus on basic and elementary STEM concepts, as well as create and enhance awareness of STEM fields and possible occupations. In conclusion, spreading the concepts of e-learning, STEM and lifelong education could have great impact on developing labor competence, enhancing socio-cultural and environmental public awareness.

\section{References}

Abbasi, F. and Zardary, S. (2012), "Digital libraries and its role on supporting E-learning AWERProcedia information technology and computer sciene", Academic World Education and Research Center, Vol. 7, pp. 809-813.

Balapanidou, A. (2015), "The challenging role of public libraries as providers of lifelong learning opportunities for personal and social skills development", International Journal of Teaching and Education, Vol. 3 No. 2, pp. 1-16, doi: 10.20472/TE.2015.3.2.001.

Bhatnagar, V. (2016), “Collaborative filtering using data mining and analysis”, IGI Global, doi: 10.4018/ 978-1-5225-0489-4.

Bilawar, P.B. (2013), "Special library: a gigantic information centre for specials", American International Journal of Research in Humanities, Arts and Social Sciences, Vol. 3 No. 2, pp. 134-140.

Chen, B., Bastedo, K. and Howard, W. (2018), "Exploring best practices for online STEM courses: active learning, interaction and assessment design”, Online Learning, Vol. 22 No. 2, pp. 59-76, doi: 10.24059/olj.v22i2.1369.

Chetty, L.R. (2012), "The role of science and technology in developing world in the 21st century", Institute for Ethics and Emerging Technologies. Ethical Technology, available at: https://ieet.org/ index.php/IEET2/more/chetty20121003 (accessed 3 December 2018).

De, B. (2018), "Traditional learning vs Online learning”, available at: https://elearningindustry.com/ traditional-learning-vs-online-learning (accessed 26 December 2018).

Eagleton, C. and Manolopoulou, A. (2017), "Paper money of england and wales", available at: https:// www.britishmuseum.org/research/publications/online_research_catalogues/paper_money/paper_ money_of_england_wales/the_industrial_revolution/the_industrial_revolution_3.aspx (accessed 3 December 2018).

Han, Y. and Yates, S. (2016), "eLearning integration in the Library: a case study", Library Managmet, Vol. 37 Nos 8-9, pp. 441-453, doi: 10.1108/LM-04-2016-0025.

Heap, T. (2017), "5 benefits of studying online (vs Face-to-Face classroom)", available at: http:// online.illinois.edu/articles/online-learning/item/2017/06/05/5-benefits-of-studying-online-(vs.face-to-face-classroom) (accessed 27 December 2018).

Kumbhar, R. (2009), "Use of E-learning in library and information science education", DESIDOC Journal of Library \& Information Technology, Vol. 29 No. 29, pp. 37-41, doi: 10.14429/djlit. 29.228 .

Lifelong Learning (2012), "Scandinavian library quarterly No. 1", available at: https://www.divaportal.org/smash/get/diva2:537588/FULLTEXT01.pdf (accessed 29 November 2018).

National Science Teachers Association (NSTA) Position Statement (2016), "The role of E-learning in science education", available at: https://www.nsta.org/about/positions/e-learning.aspx (accessed 3 December 2018).

Porter, D. (1959), "Some effects of year long teaching machine instruction", in Galanter, E. (Ed.), Automatic Teaching: The State of the Art, John Wiley, New York, NY, pp. 85-90.

Proudfoot, D.E. and Kebritchi, M. (2017), "Scenario-based E-learning and STEM education: a qualitative study exploring the perspectives of educators", International Journal of Cognitive Research in Science, Engineering and Education (IJCRSEE), Vol. 5 No. 1, pp. 7-18, doi: 10.5937/ ijcrsee1701007p. 
Purdue University Global (2018), "Classroom vs Online education: which one is better for you?" available at: https://www.purdueglobal.edu/blog/student-life/classroom-versus-online/ (accessed 26 December 2018).

Rajput, P.S. (2013), "Digital library: an emerging paradigm towards open access", in Ashraf, T. and Gulati, P.A. (Eds), Design, Design, Development, and Management of Resources for Digital Library Services, IGI Global, Hershey, PA, pp. 110-118, doi: 10.4018/978-1-4666-2500-6.ch010.

Sharifabadi, S.R. (2006), "How digital libraries can support E- learning", The Electronic Library, Vol. 24 No. 3, pp. 389-401, doi: 10.1108/02640470610671231.

Shukla, S.S., Singh, K.A.P. and Mishra, A.K. (2013), "The role of libraries in literacy and education prerequisite for education and sustainable development at all levels of education", IOSR Journal of Humanities and Social Science (IOSR-JHSS), Vol. 14 No. 5, pp. 35-40. available at: www. Iosrjournals.Org (accessed 29 November 2018).

Suppes, P. (1964), "Modern learning theory and the elementary-school curriculum", American Educational Research Journal, Vol. 1, pp. 79-93.

The International Federation of Library Associations and Institutions /the United Nations Educational, Scientific and Cultural Organization IFLA/UNESCO Public Library Manifesto, 1994 (2016), available at: https://www.ifla.org/publications/iflaunesco-public-library-manifesto1994 (accessed 29 November 2018).

Tiwari, R.K. (2011), "Library services in distance education System: in Indian context", International Journal of Librarianship and Administration, Vol. 2 No. 1, pp. 1-11. available at: http://www. ripublication.com/ijla.htm (accessed March 2018).

Trivedi, M. (2010), "Digital libraries: functionality, usability, and accessibility", Library Philosophy and Practice (e-journal), available at: http://digitalcommons.unl.edu/libphilprac/381 (accessed January 2019).

Uttal, W.R. (1962), "On conversational interaction”, in Coulson, J.E. (Ed.), Programmed Learning and Computer-based Instruction, John Wiley, New York, NY, pp. 171-190.

Versteijlen, M., Salgado, F.P., Groesbeek, M.J. and Counotte, A. (2017), "Pros and cons of online education as a measure to reduce carbon emissions in higher education in The Netherlands", Current Opinion in Environmental Sustainability, Elsevier B.V., Vol. 28, pp. 80-89, doi: 10.1016/j. cosust.2017.09.

\section{Further reading}

Tocatlian, J. (1991), "Bibliotheca Alexandrina - reviving a legacy of the past for a brighter common future”, International Library Review, Vol. 23 No. 3, pp. 255-269, doi: 10.1016/0020-7837(91) 90034-W.

\section{Corresponding author}

El-Shaimaa Talaat Abumandour can be contacted at: elshaimaa.talaat@bibalex.org
Role of public libraries in e-learning 
JRIT
14,2

Annex 1

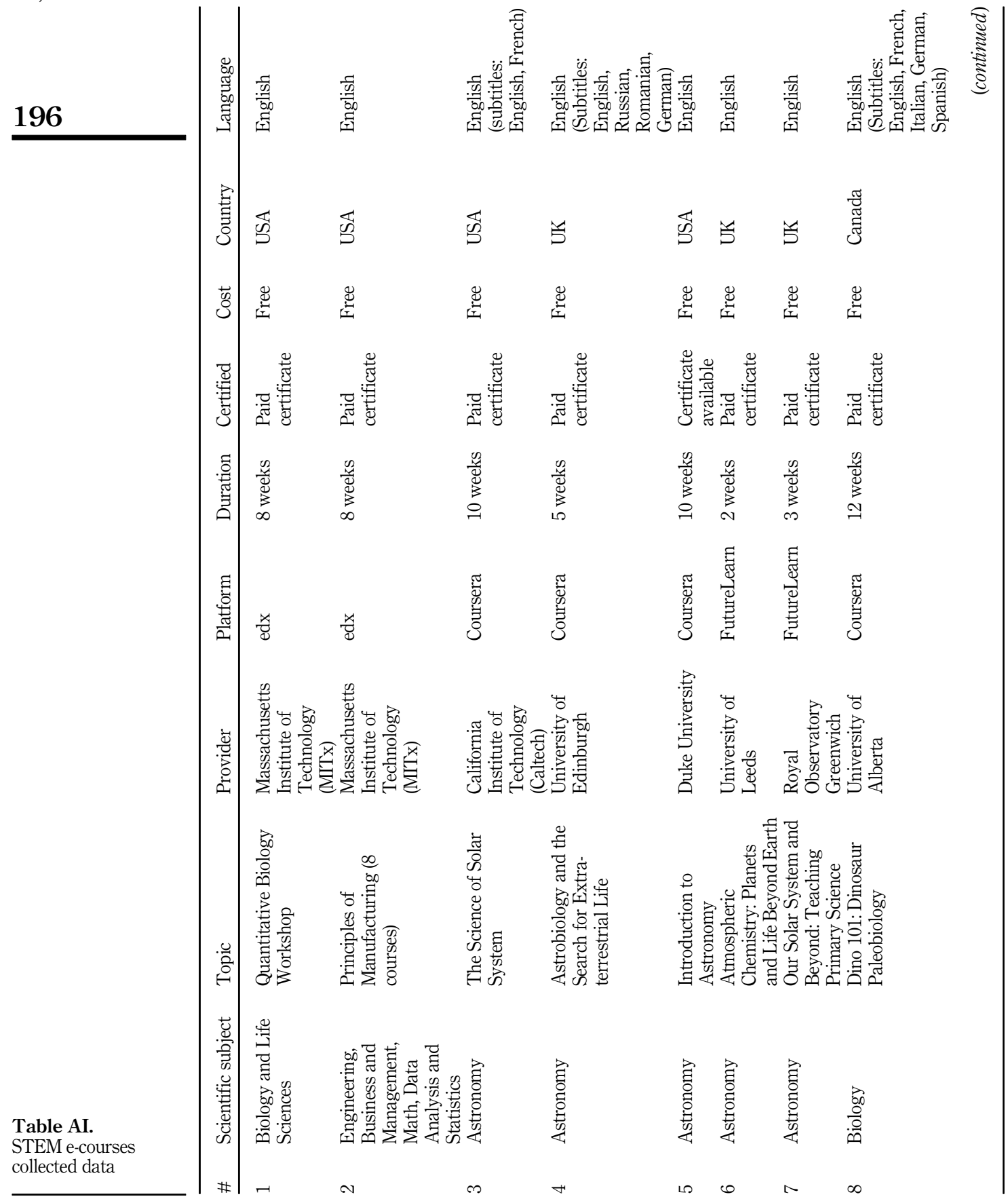




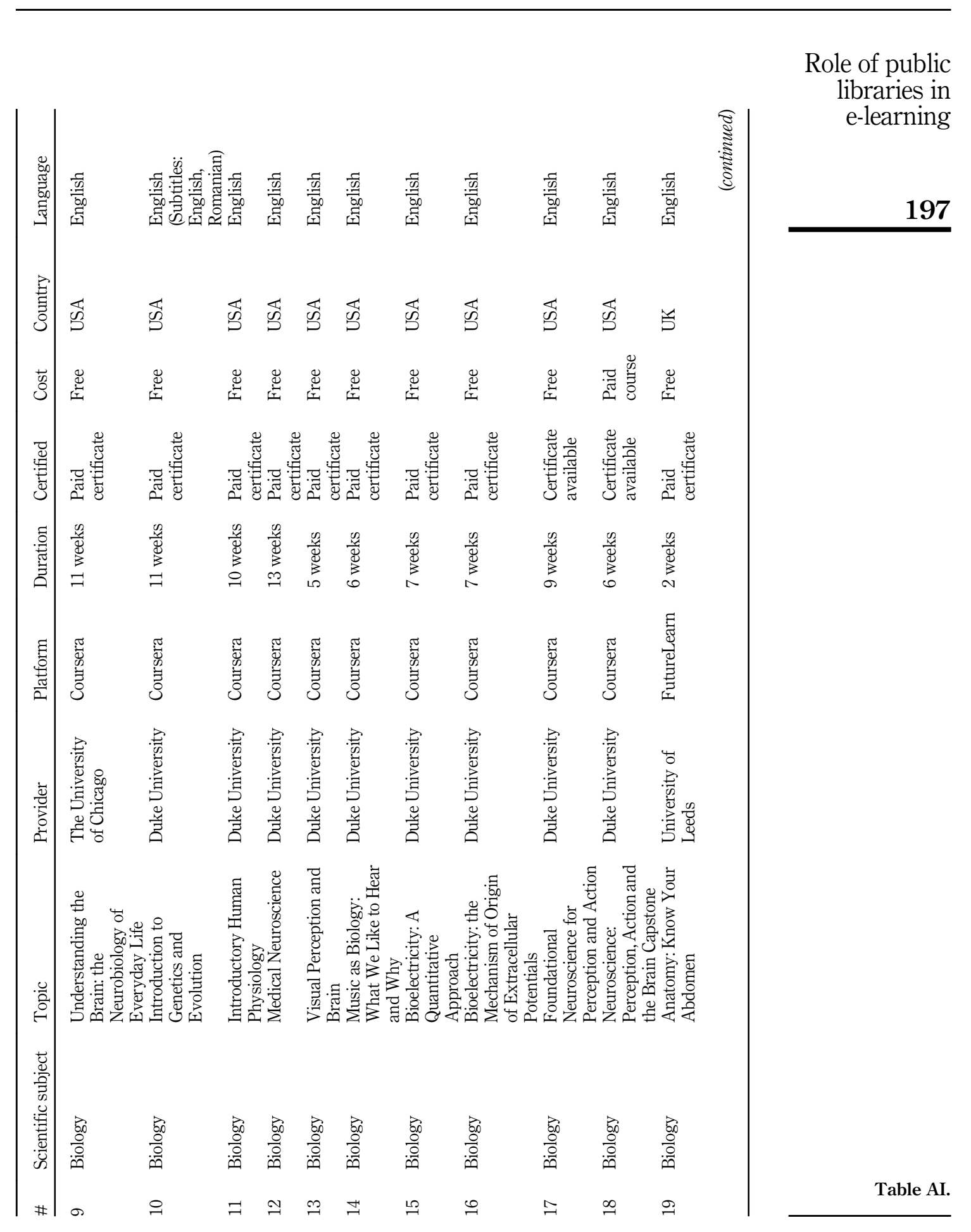


JRIT
14,2

198

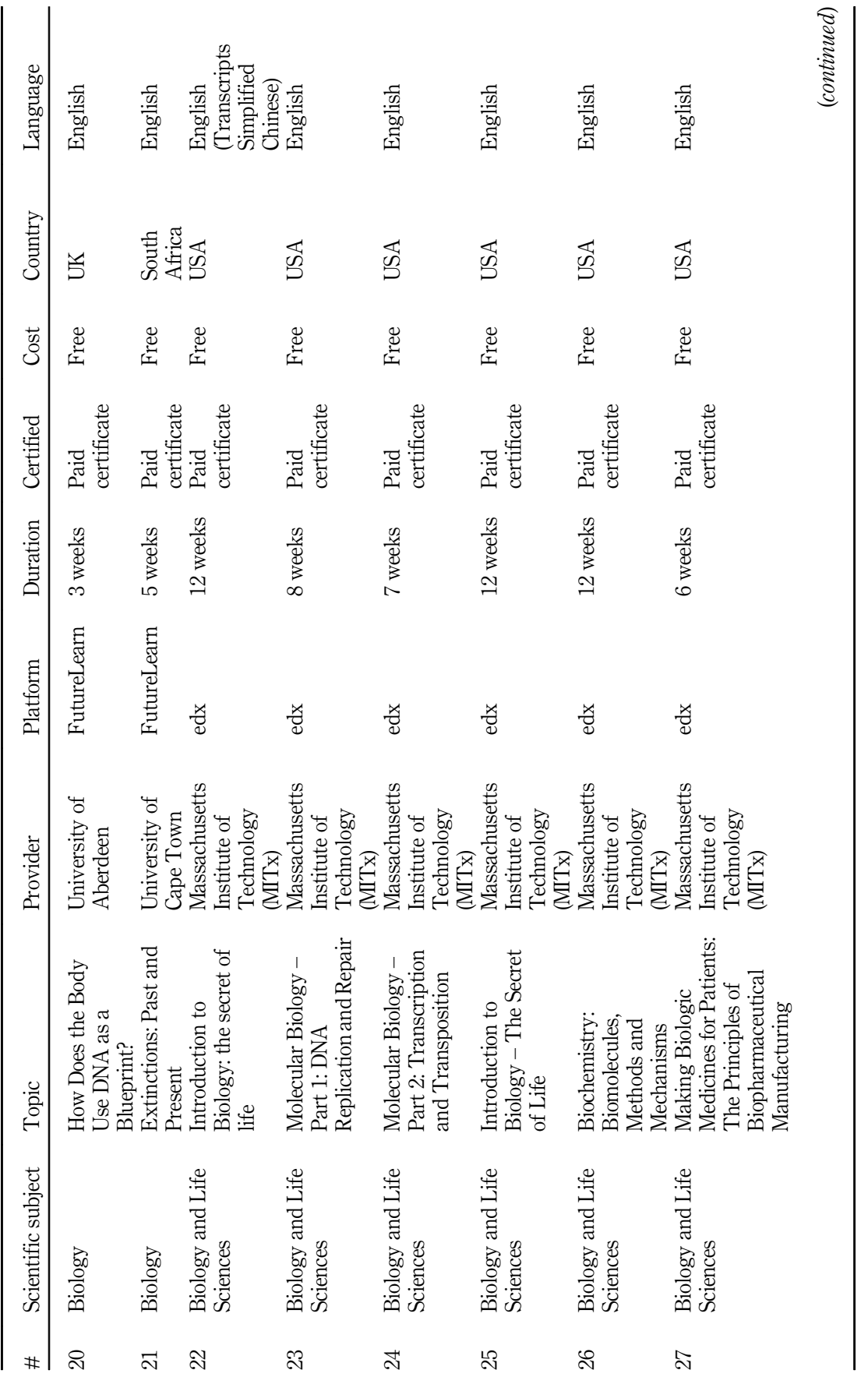




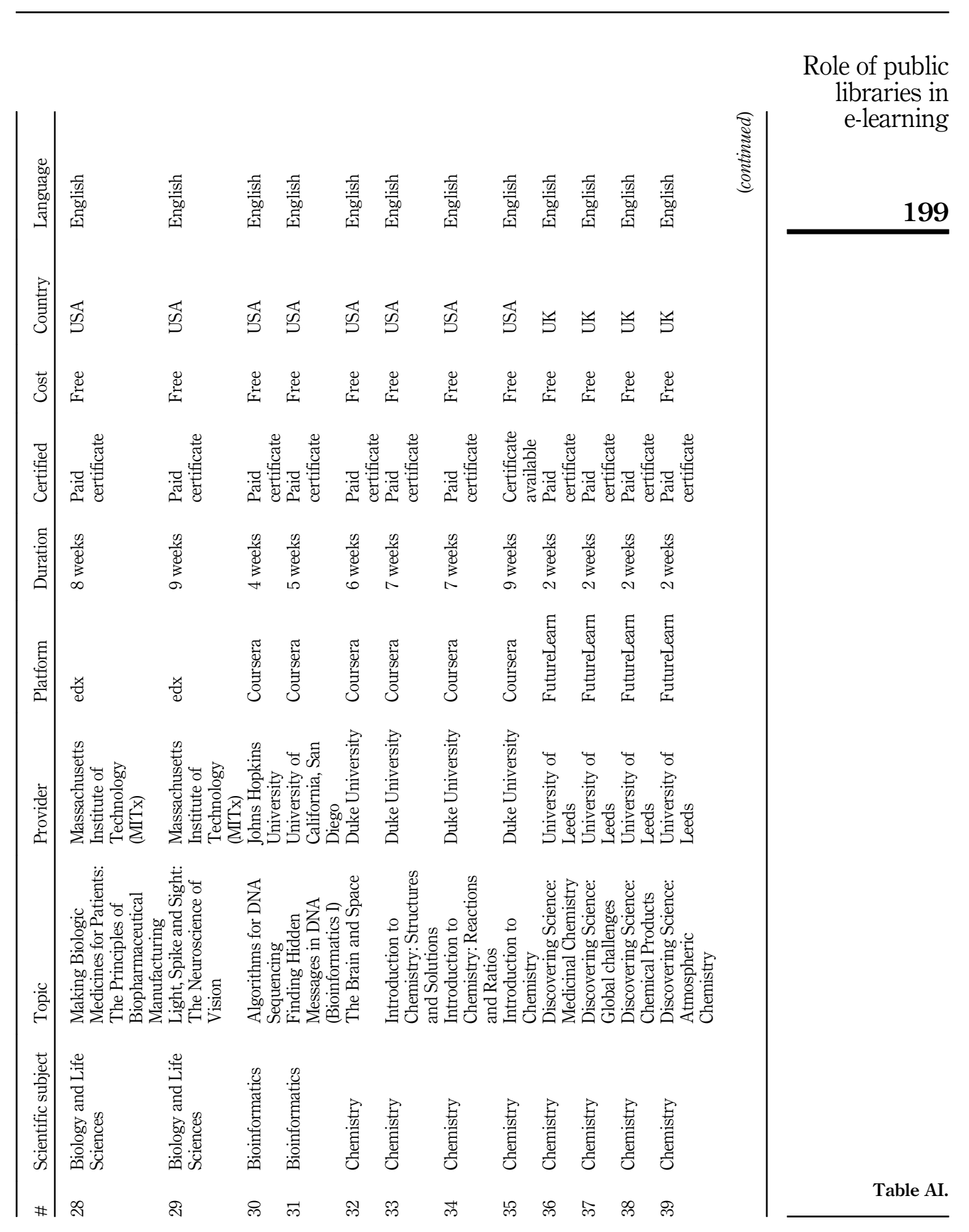




\section{JRIT \\ 14,2}

\section{0}

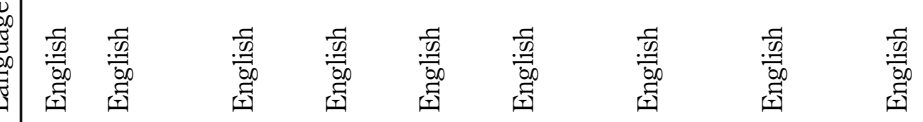

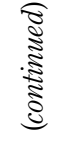

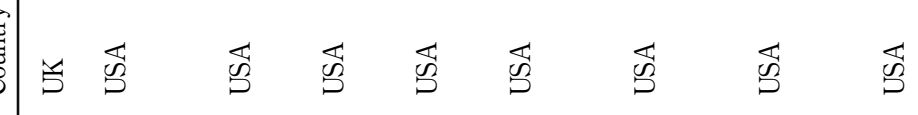

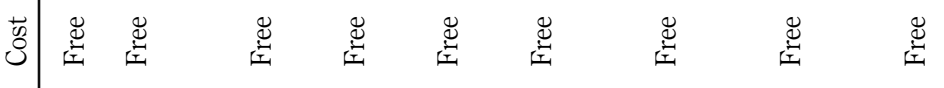

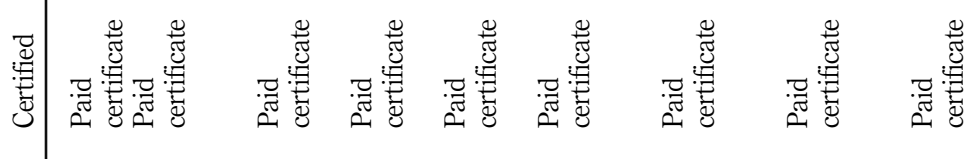

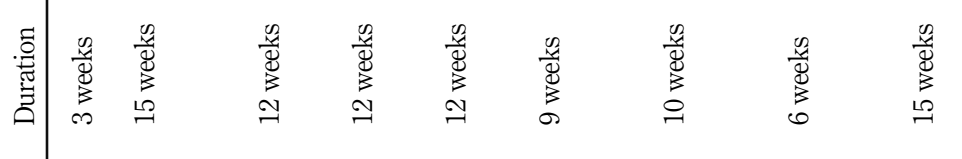

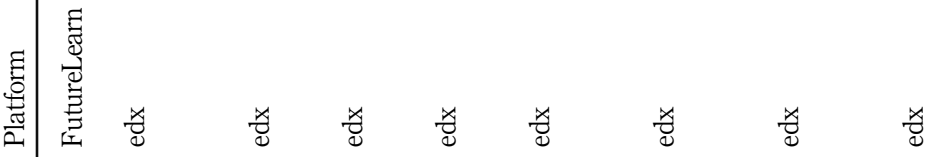

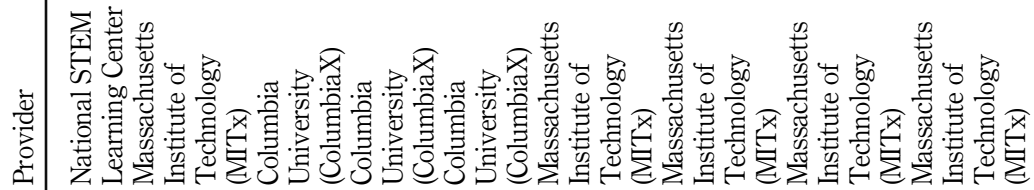

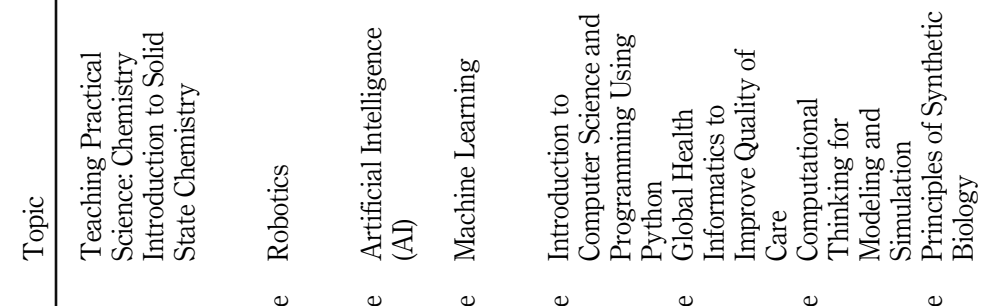

Table AI.

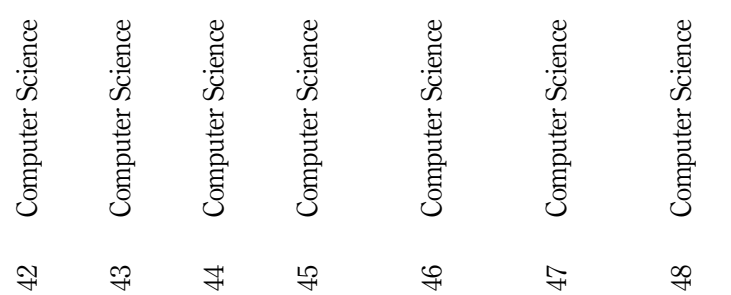




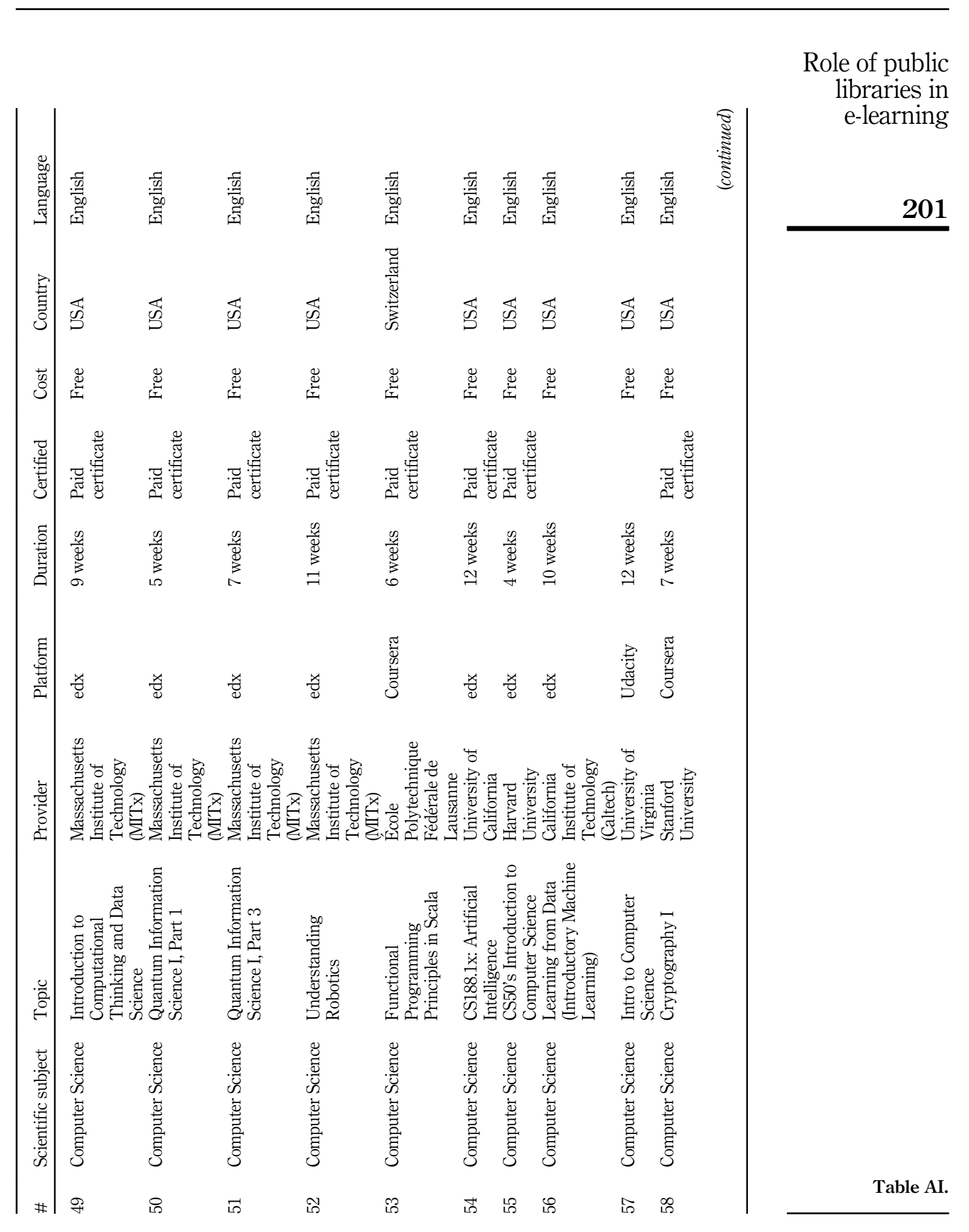


JRIT
14,2

202

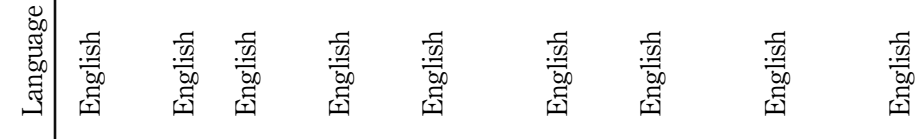

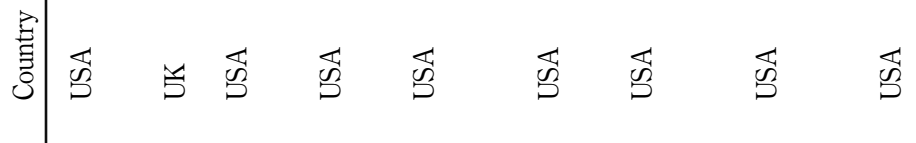

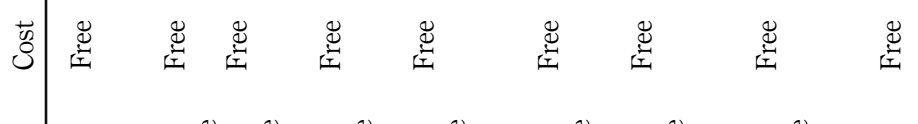

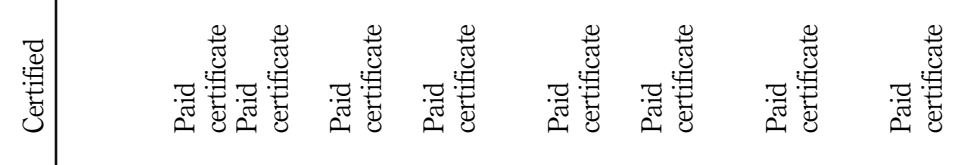

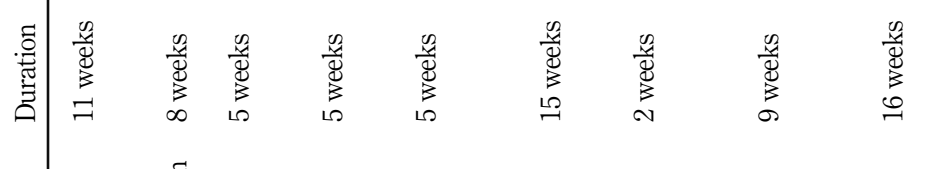

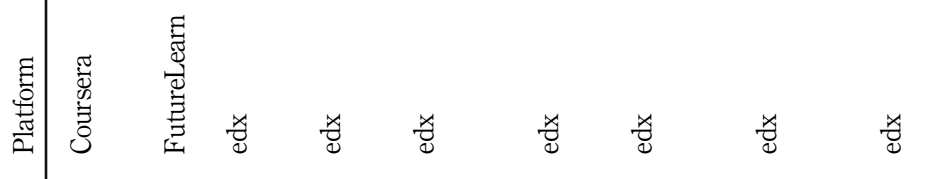

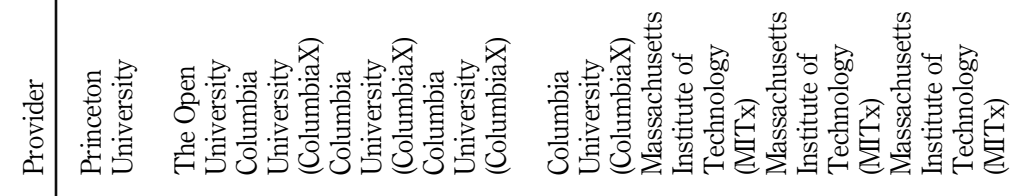

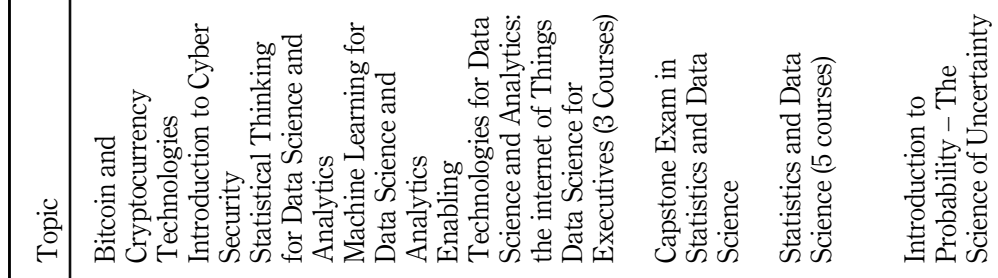

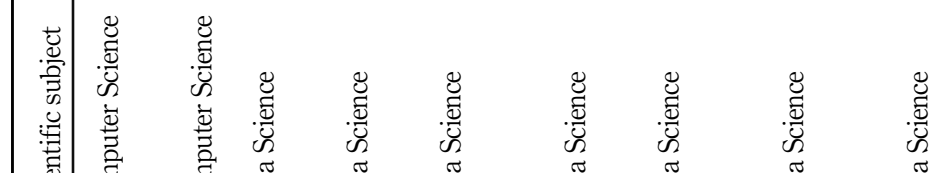

Table AI. 


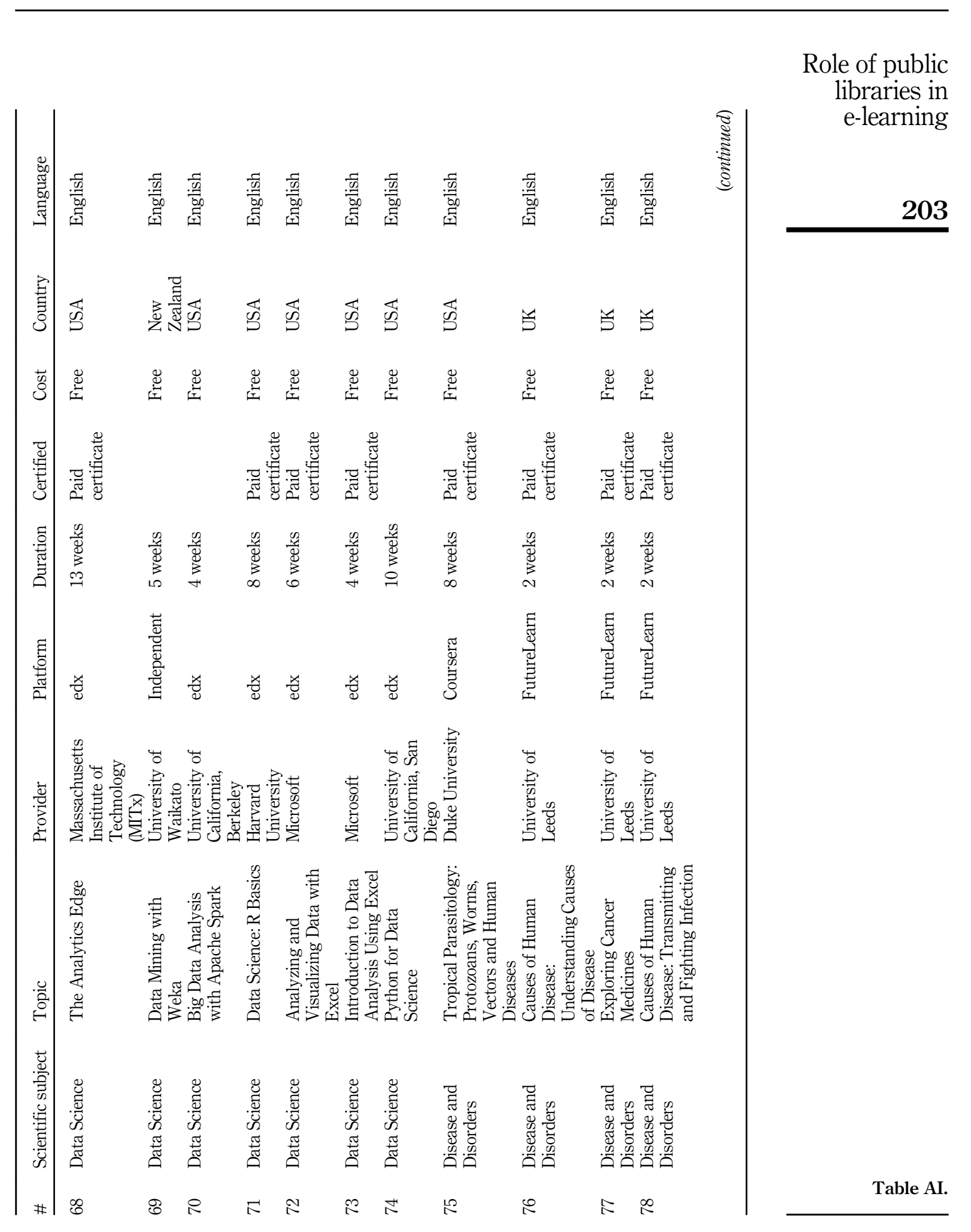


JRIT
14,2

\section{4}

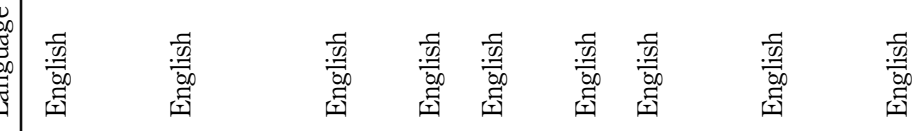

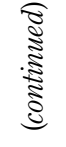

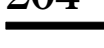

Table AI.

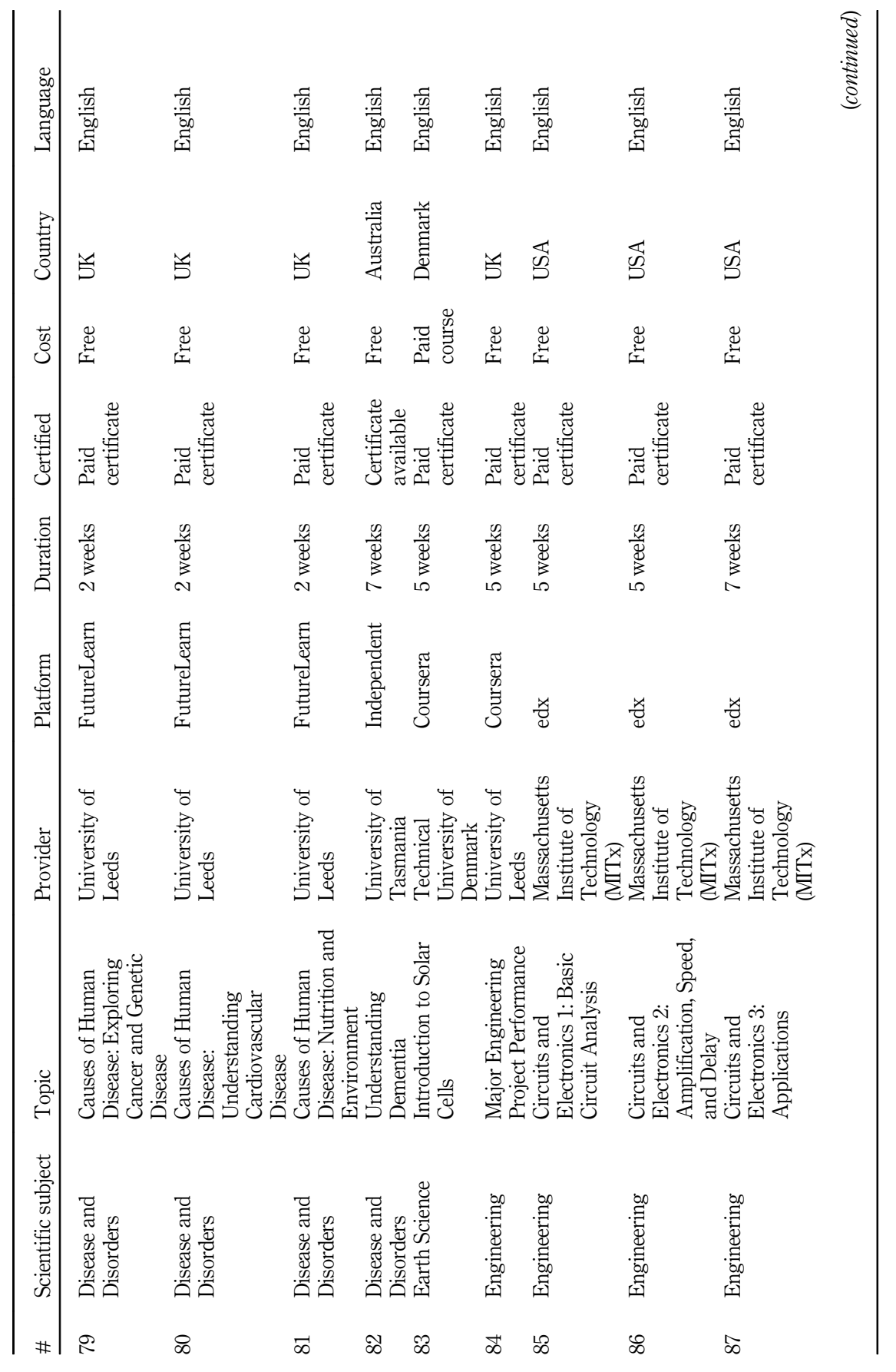




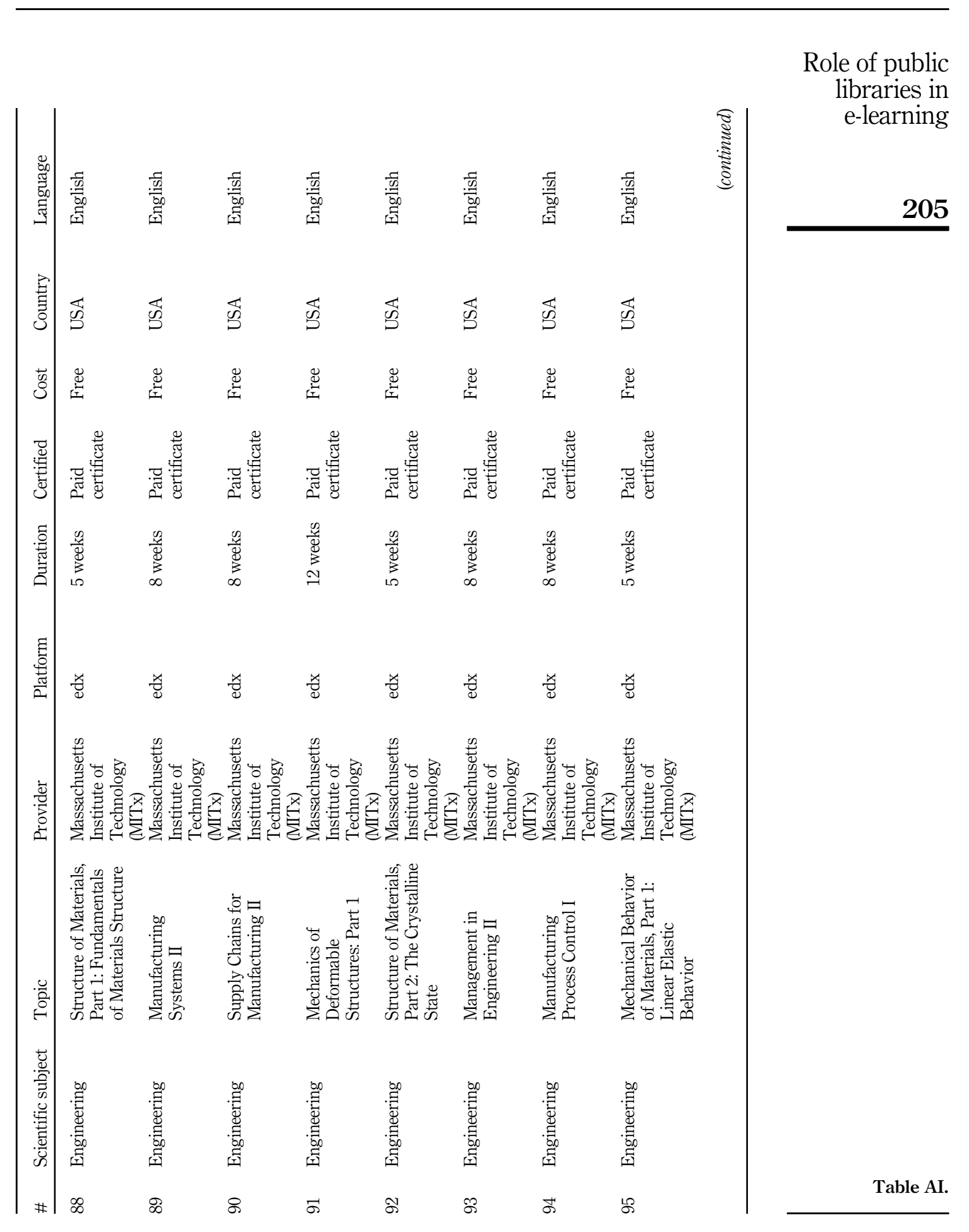




\section{JRIT \\ 14,2}

206

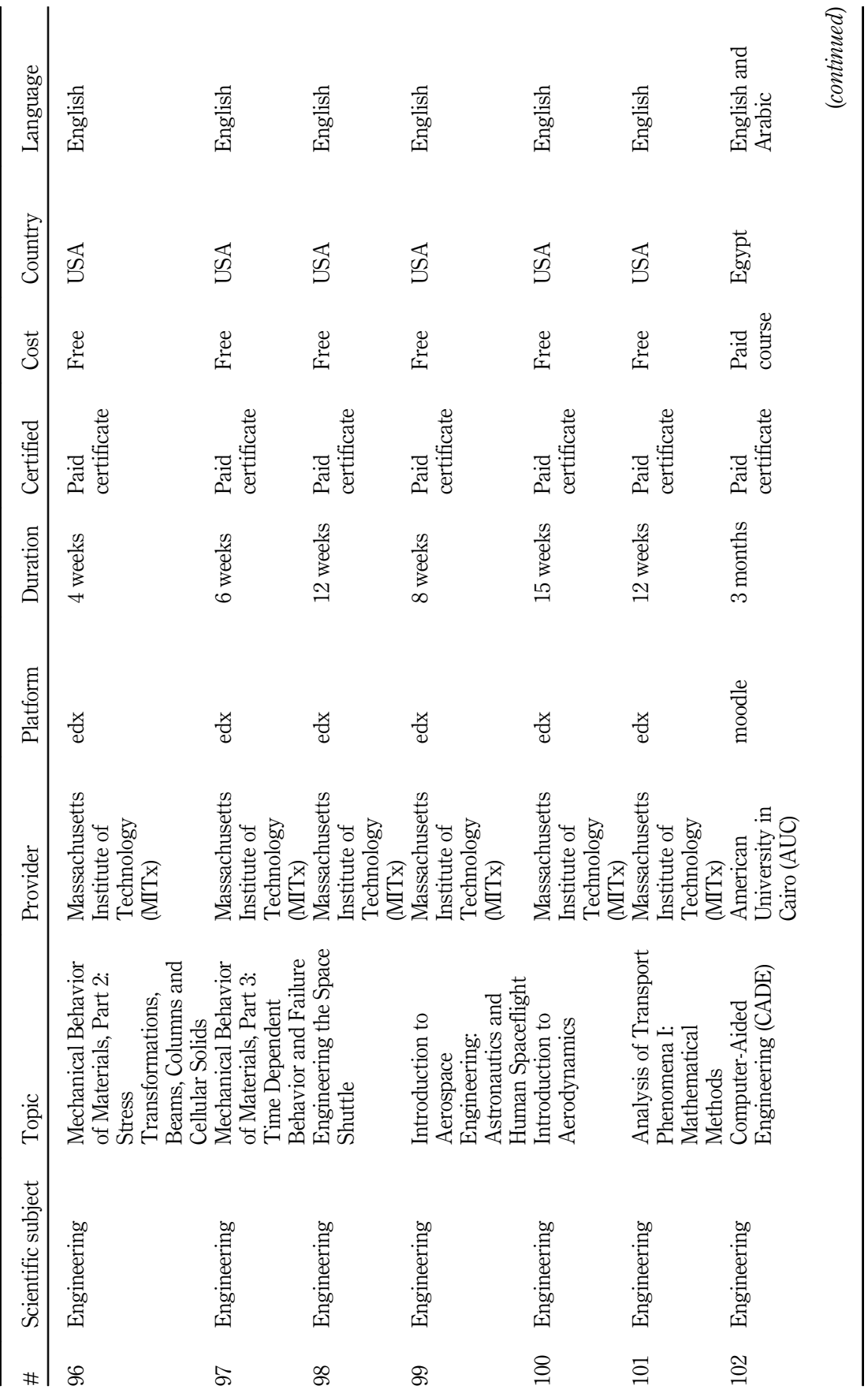




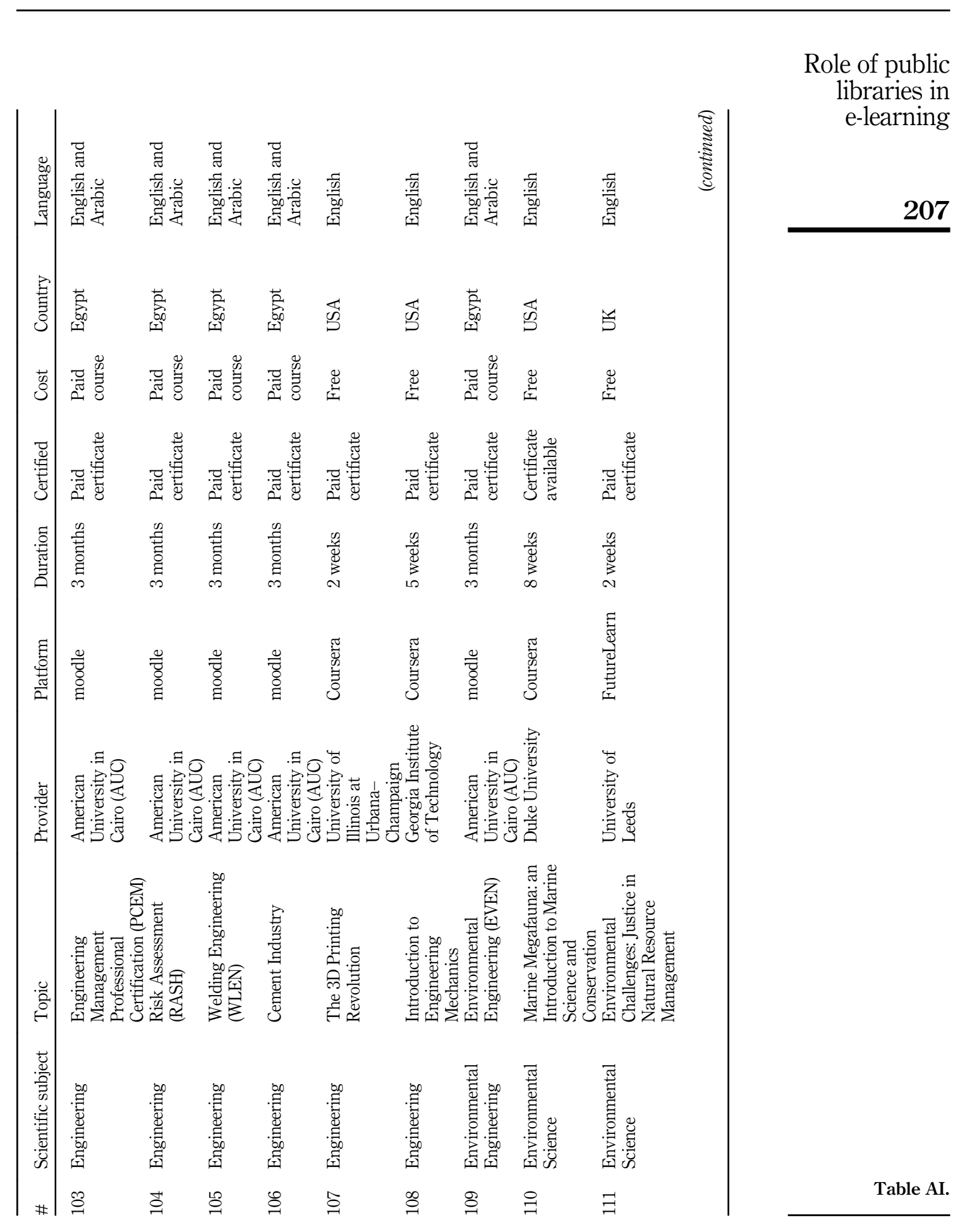


JRIT
14,2

\section{8}

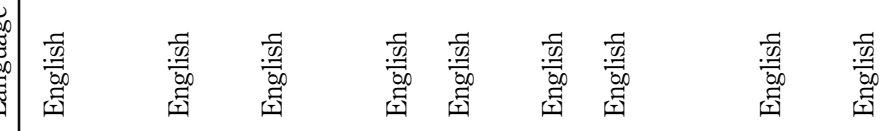

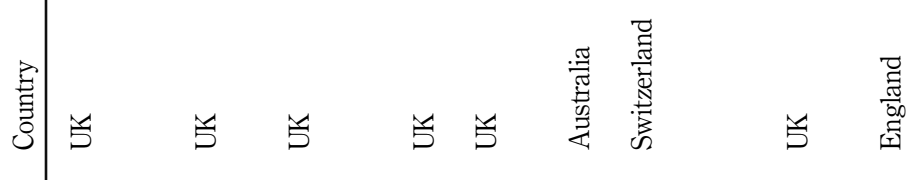

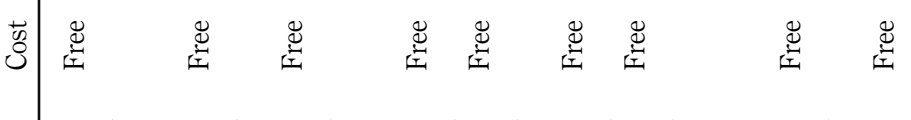

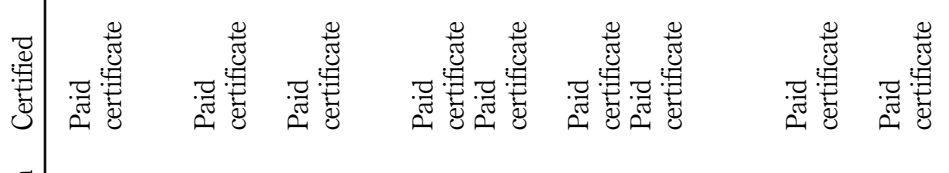

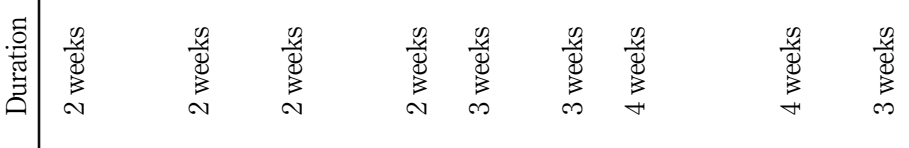

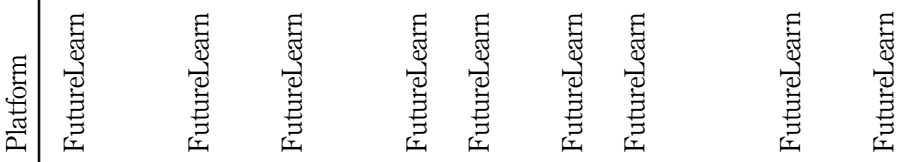

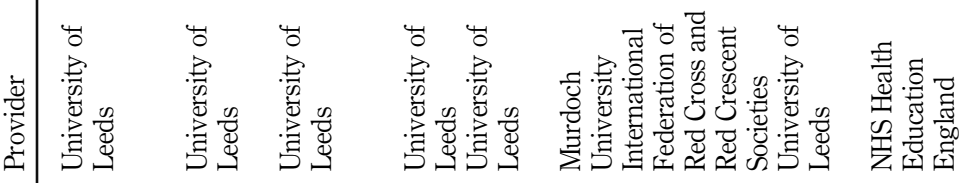

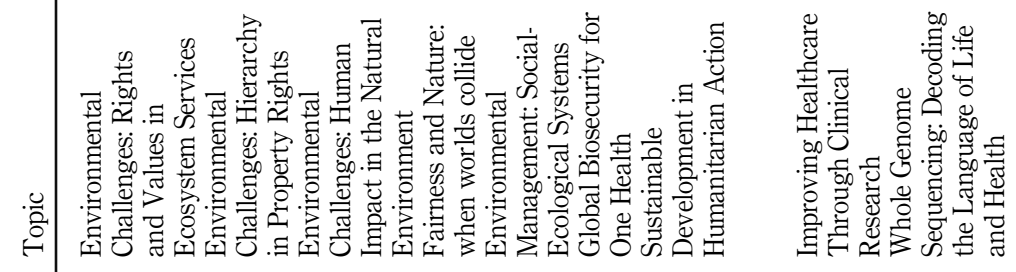

Table AI.

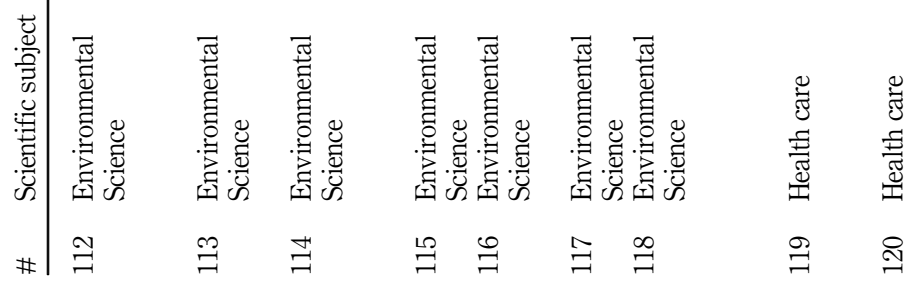




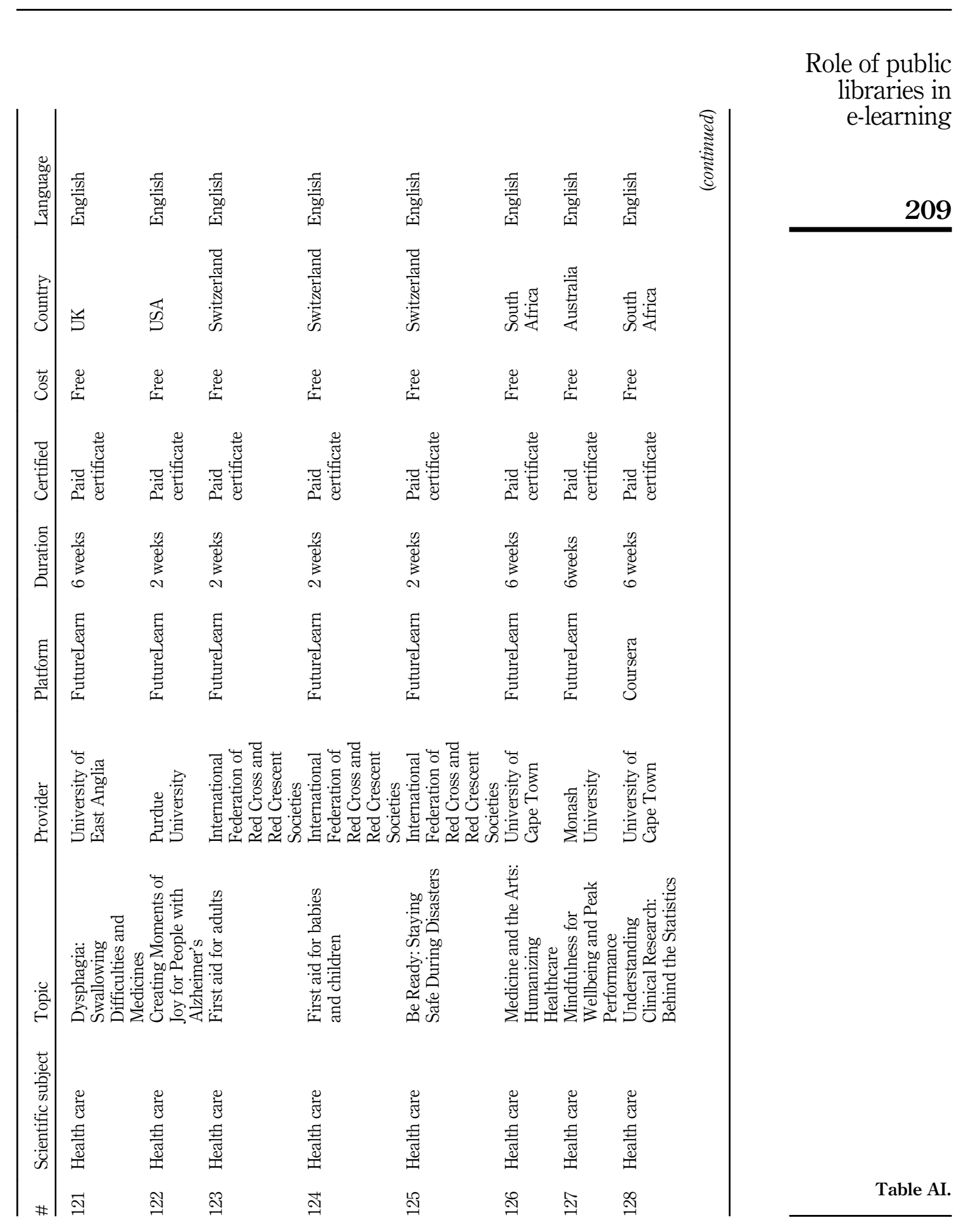


JRIT
14,2

\section{0}

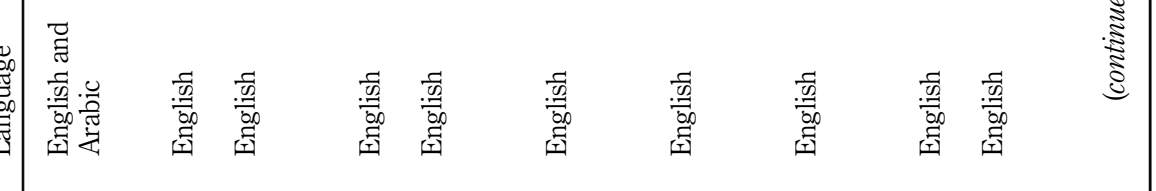

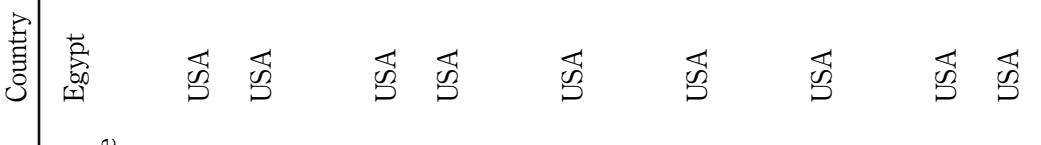

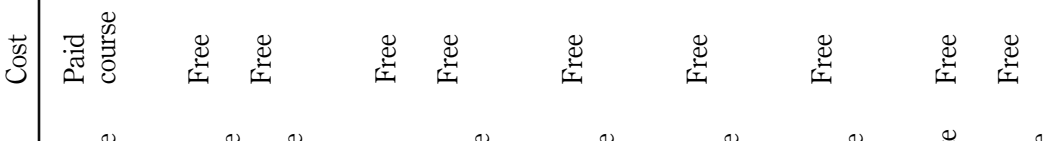

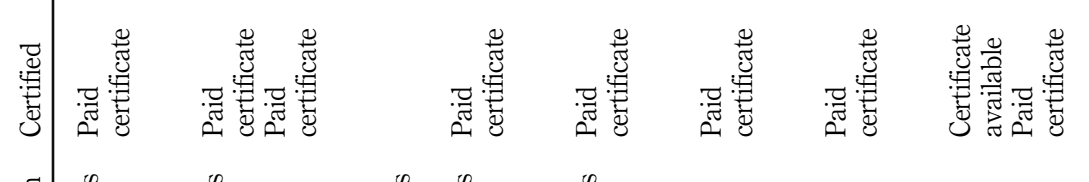

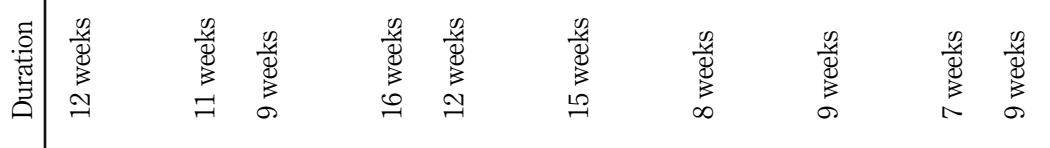

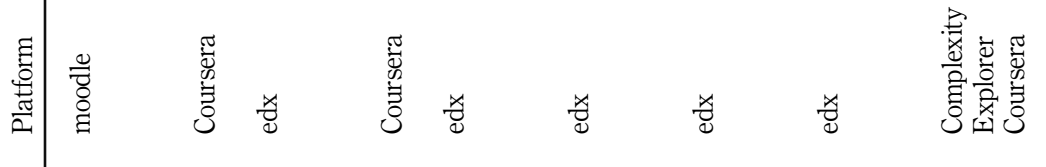

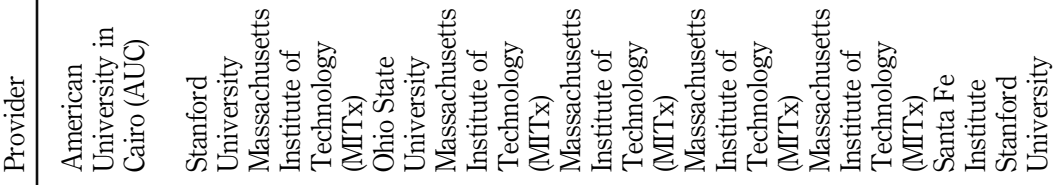

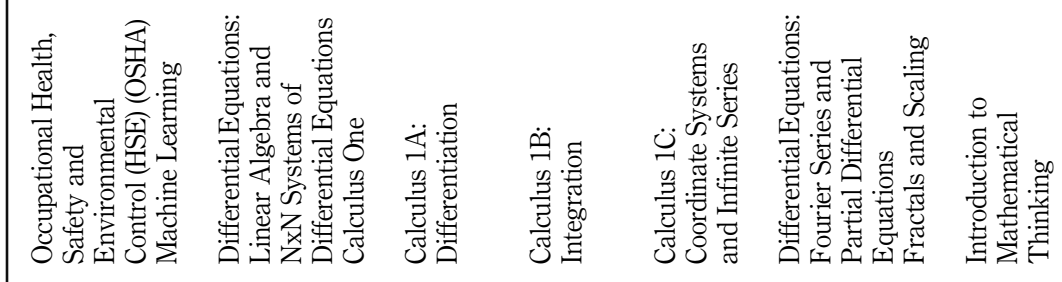

Table AI. 


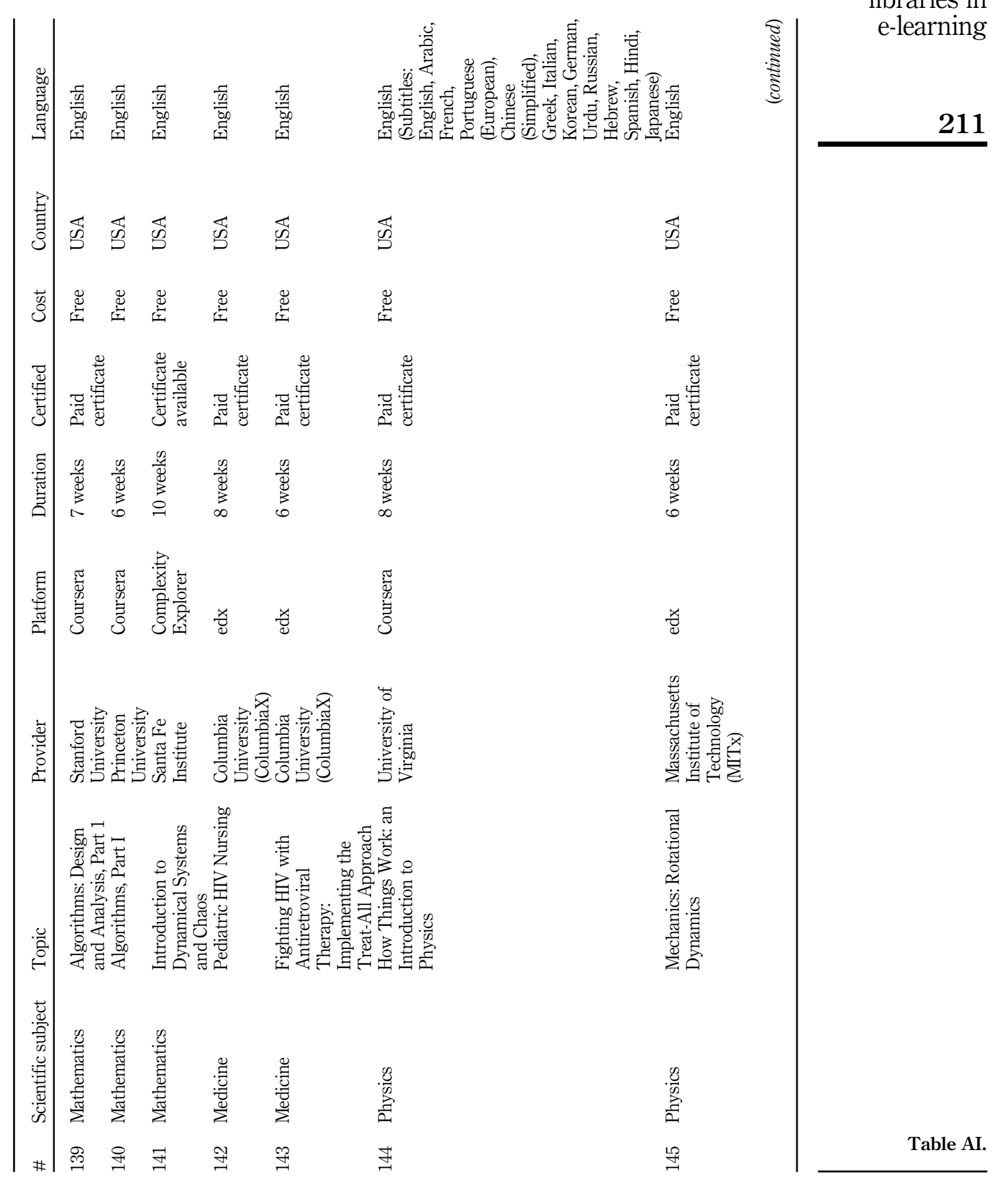


JRIT
14,2

212

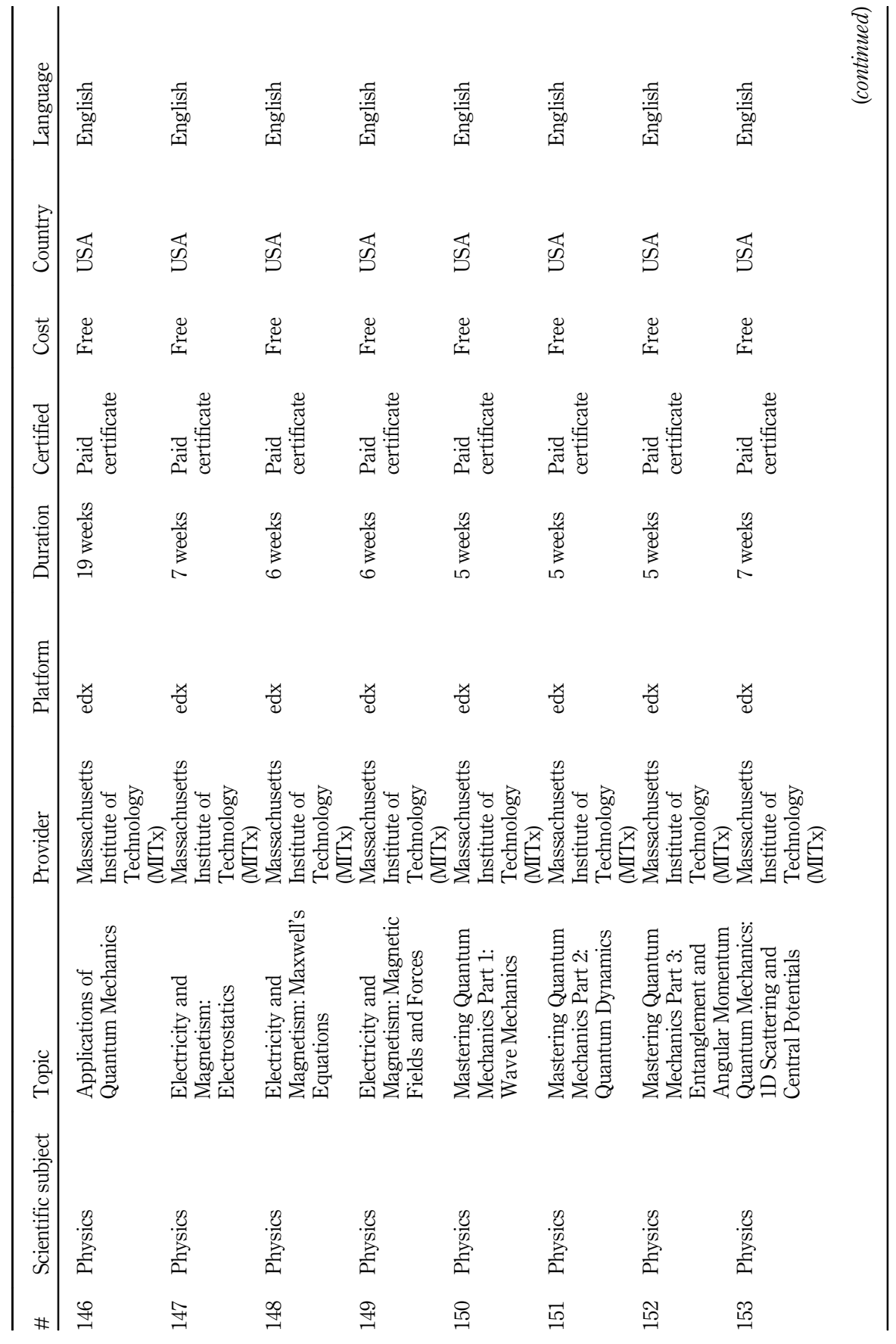




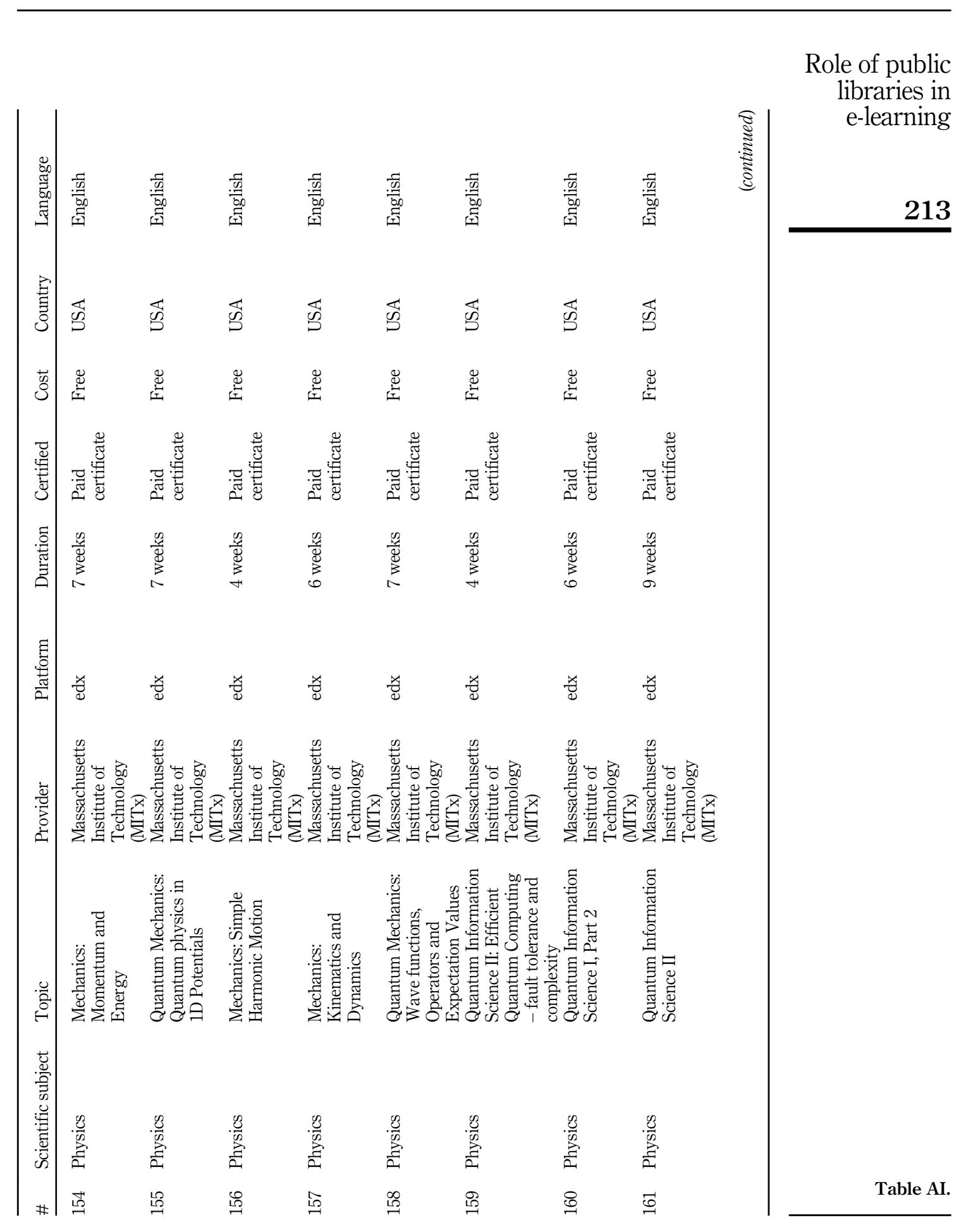


JRIT
14,2

214

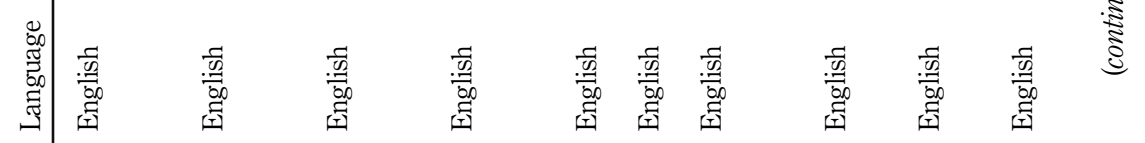

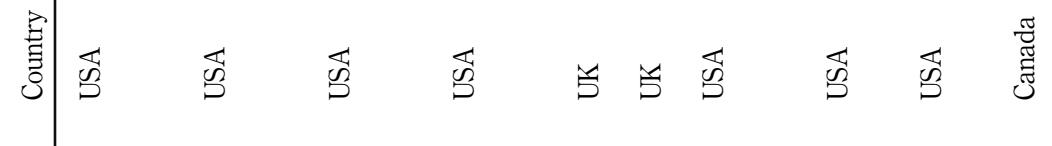

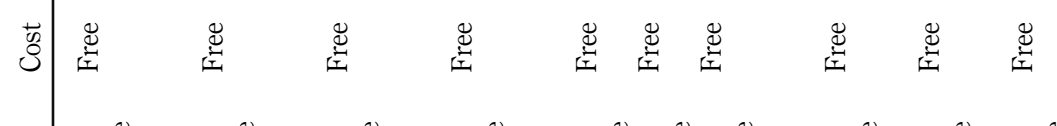

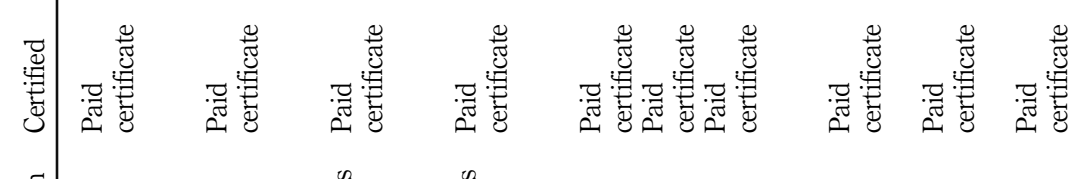

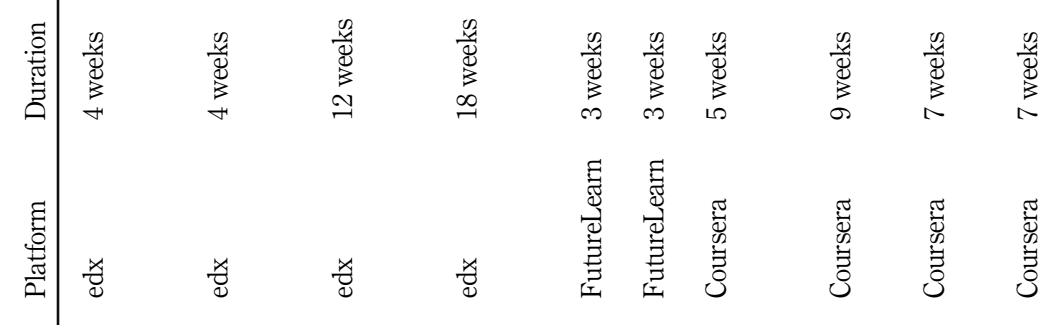

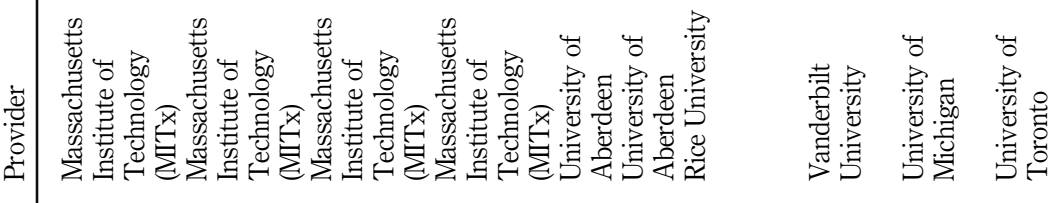

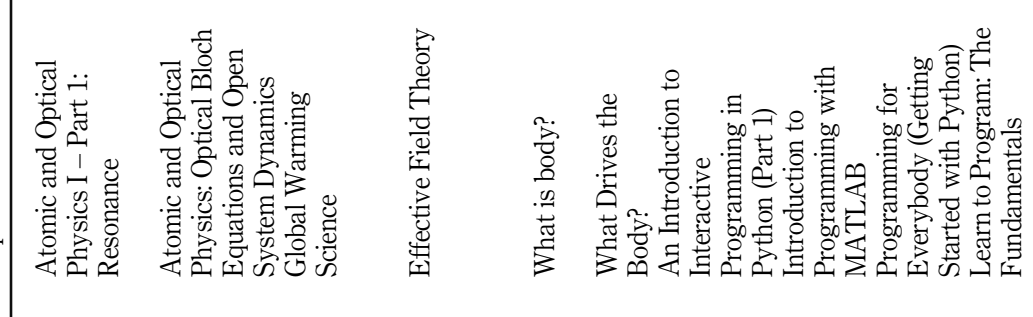

Table AI. 


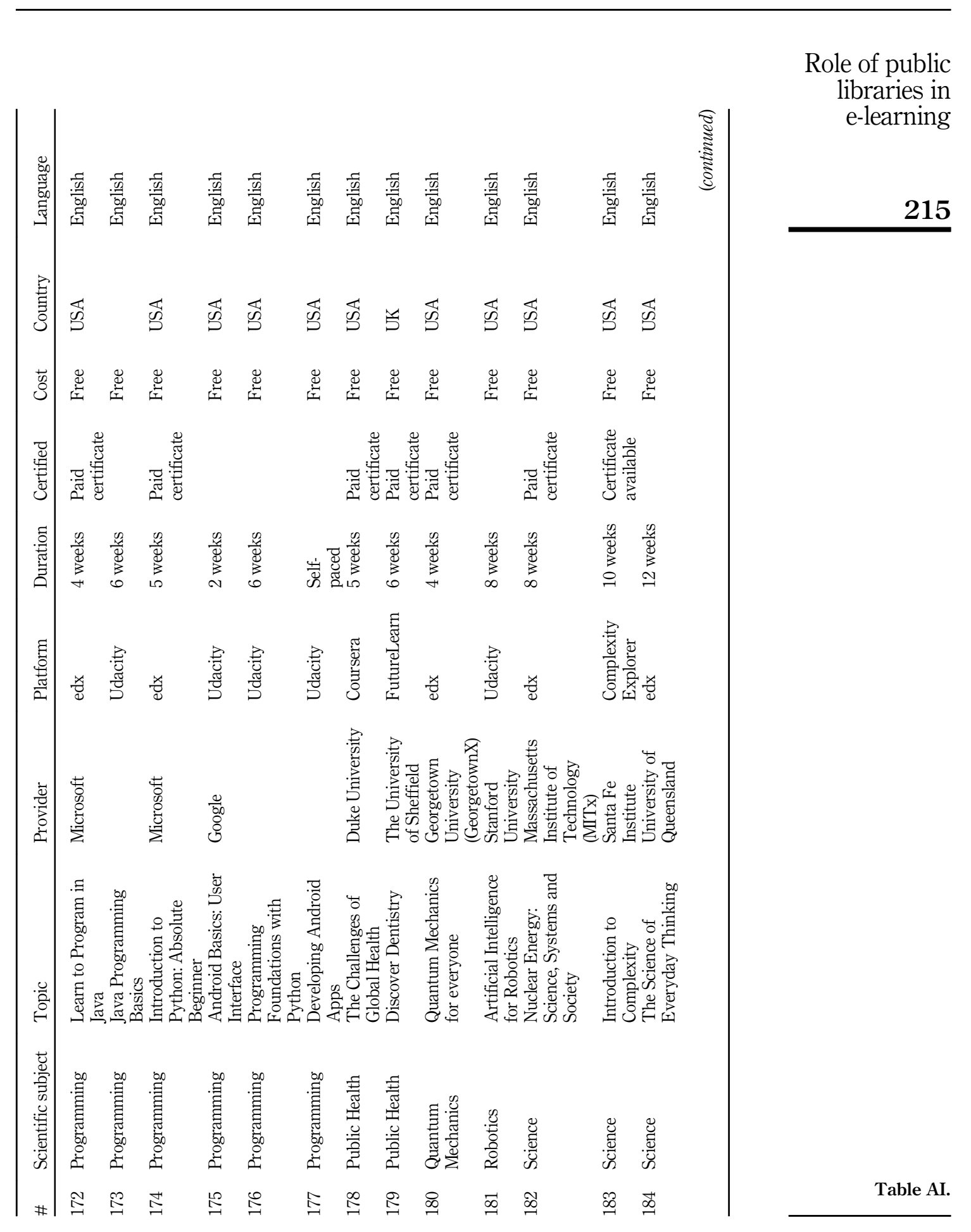




\section{JRIT}

14,2

\section{6}

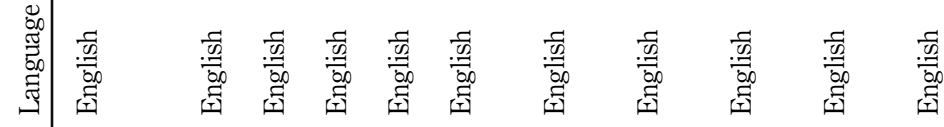

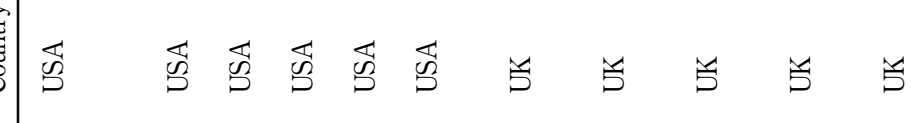

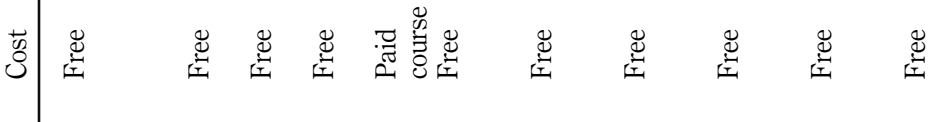

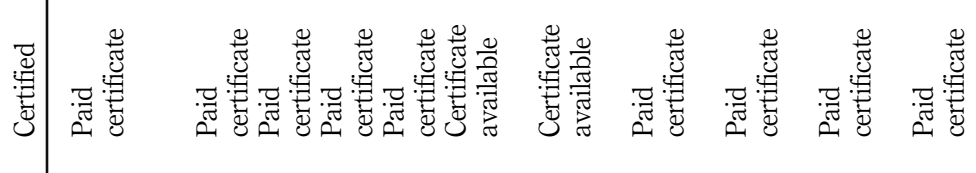

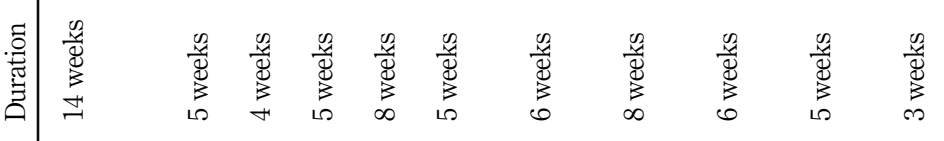

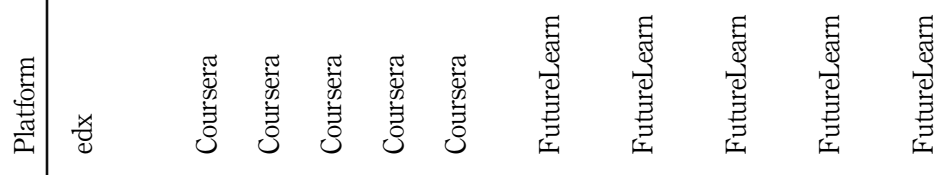

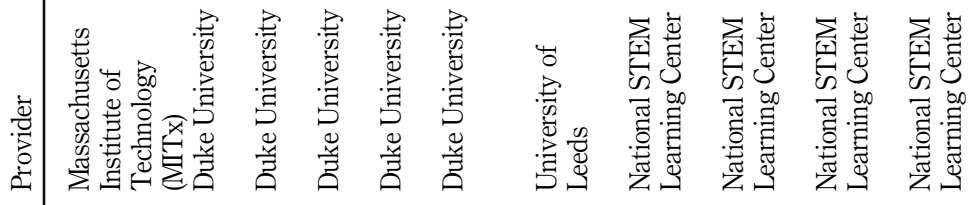

Table AI.

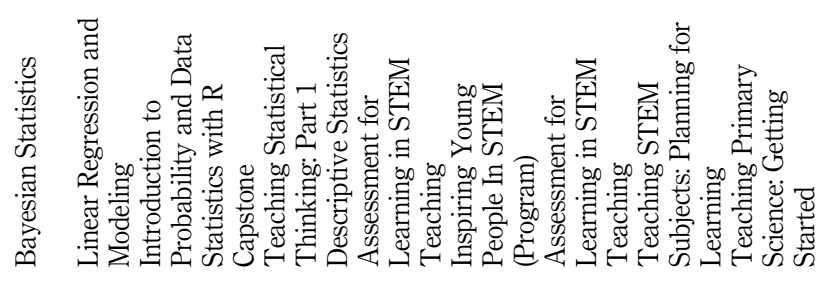

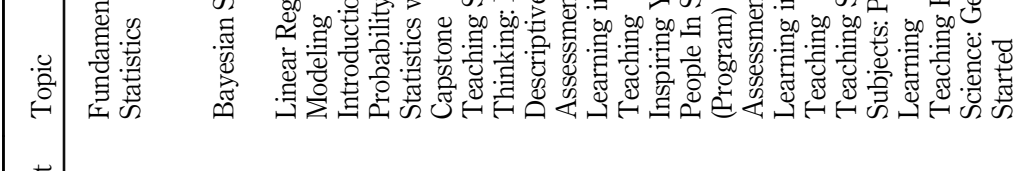

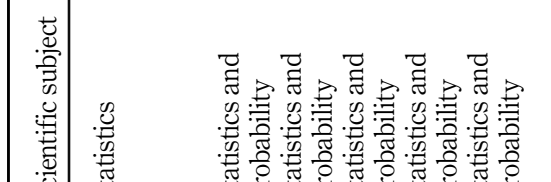

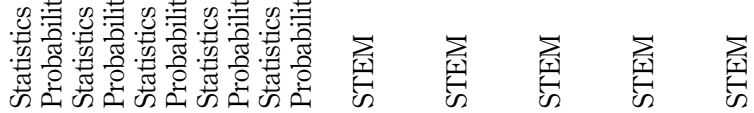

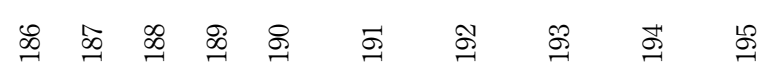


Role of public libraries in e-learning

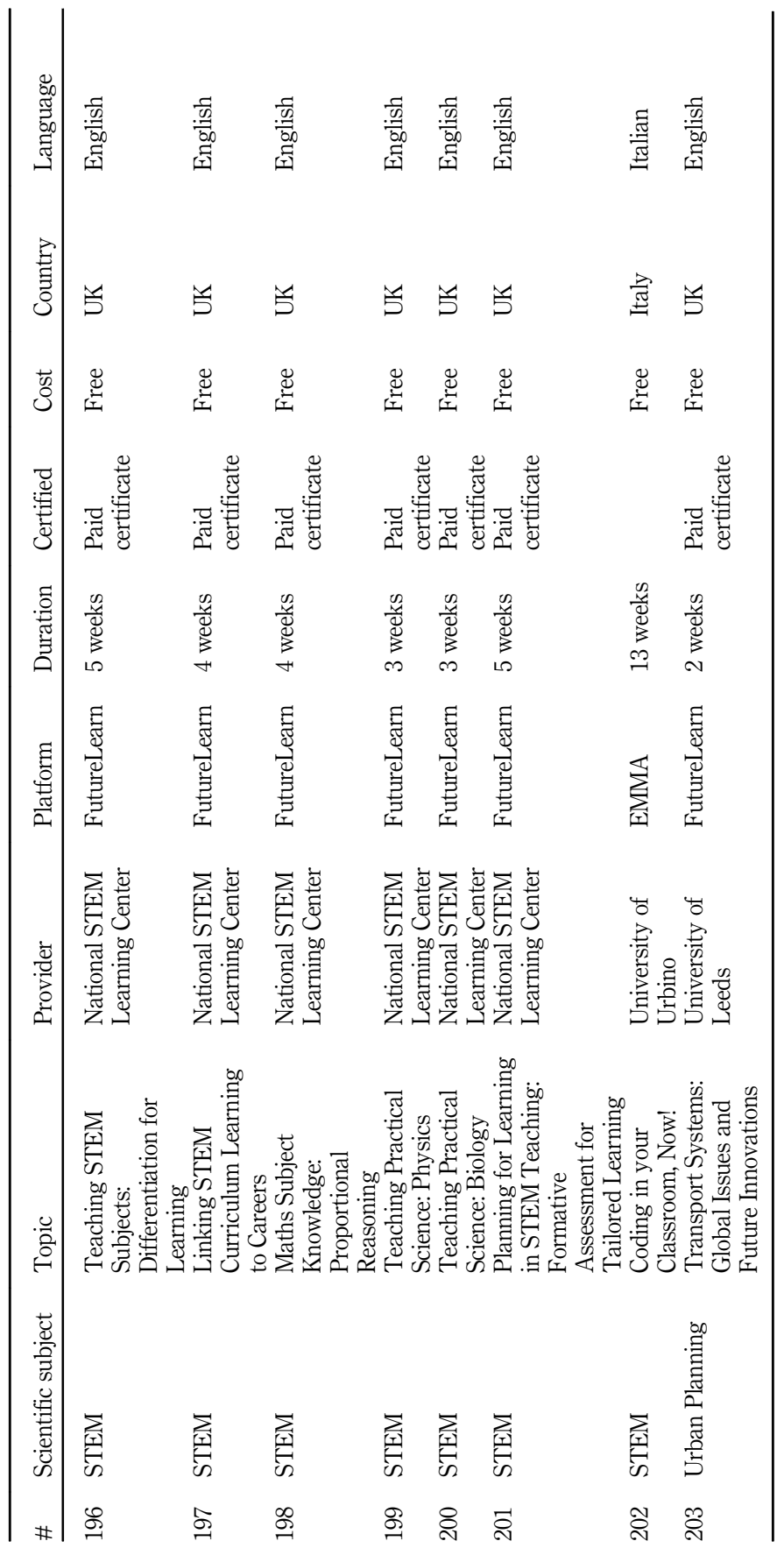

